\title{
48. RESULTS OF DETAILED GEOLOGICAL AND GEOPHYSICAL MEASUREMENTS AT ODP SITES 645 IN BAFFIN BAY AND 646 AND 647 IN THE LABRADOR SEA ${ }^{1}$
}

\author{
S. P. Srivastava, ${ }^{2}$ K. E. Louden, ${ }^{3}$ S. Chough, ${ }^{4}$ D. Mosher, ${ }^{2}$ B. D. Loncarevic, ${ }^{2}$ \\ P. Mudie, ${ }^{2}$ A. de Vernal, ${ }^{5}$ and B. MacLean ${ }^{2}$
}

\begin{abstract}
Detailed geophysical and geological measurements were conducted during a site-survey cruise to Sites 646 and 647 in the Labrador Sea. These included gravity, magnetic, bathymetry, high-resolution and deep-penetration seismic reflection, seismic refraction, and heat-flow measurements. A second cruise, which was not so extensive, involved collection of high-resolution seismic-reflection measurements and of sediment cores in Baffin Bay at Site 645. A limited number of piston cores were also collected at Sites 646 and 647 . The seismic data from these cruises have been used to identify a number of prominent reflectors that show different characteristics among the sites. Magnetic, gravity, and seismic data have been used to differentiate between rough and smooth basement topography at the Labrador sites. We suggest that the changes in basement character resulted from the change in the direction of spreading. High-resolution seismic data at the Baffin Bay site suggest the possibility of a slump feature in the top $90 \mathrm{~m}$ of the section near the site.
\end{abstract}

\section{INTRODUCTION}

Sites 646 and 647 in the Labrador Sea and Site 645 in Baffin Bay were selected for drilling during Leg 105 of the Ocean Drilling Program (ODP). These sites were selected on the basis of compiled information from a large amount of geological and geophysical data collected by the Bedford Institute of Oceanography, other research institutions, and the oil exploration industry over the past $20 \mathrm{yr}$. However, additional data at each site were needed to obtain detailed knowledge of the underlying structure and geology so that the locations of these sites could be assessed from safety and pollution points of view. This study describes the details and results of the cruises aboard the research vessel Hudson (operated by the Bedford Institute of Oceanography) undertaken in 1984 and 1985 to the Labrador Sea and Baffin Bay, respectively. The correlation of drilling results to data at each of these sites and their implications to the paleoceanography and tectonic development of these regions are dealt with elsewhere in this volume and will not be repeated here. We present here most of the seismic data collected at these sites, to make them easily accessible.

Unlike the Labrador Sea sites, adequate multichannel seismic data existed for the Baffin Bay site, and additional data were not required to assess its suitability before drilling. However, to extend the drilling results for the upper $200 \mathrm{~m}$ section at this site to the neighboring regions, high-resolution seismic and coring data were collected in the vicinity of this site on a cruise aboard the Hudson in 1985. These data are also included here.

Drilling at these Labrador Sea and Baffin Bay sites was proposed (1) to study the tectonic development of these regions, (2) to study the history of deep- and surface-water paleocirculations through these regions, and their connection to the Arctic and Atlantic oceans, and (3) to study the paleoclimatic condi-

${ }^{1}$ Srivastava, S. P., Arthur, M., Clement, B., et al., 1989. Proc. ODP, Sci. Results, 105:College Station, TX (Ocean Drilling Program).

2 Geological Survey of Canada, Atlantic Geoscience Centre, Bedford Inst. of Oceanography, Dartmouth, Nova Scotia B2Y 4A2, Canada.

${ }^{3}$ Department of Oceanography, Dalhousie University, Halifax, Nova Scotia B3H $4 \mathrm{J1}$, Canada.

${ }^{4}$ Department of Oceanography, Seoul National University, Seoul 151, Korea.

5 Departement de Sciences de la Terre GEOTOP, Université du Québec á Montréal, CP 8888 Succursale "A," Montréal, Québec H3C 3P8, Canada. tions and the timing and frequency of climatic oscillations, particularly glacial and interglacial cycles that prevailed in these regions. Details of these objectives together with some background information on the geological and paleoenvironmental setting of these basins were described by Srivastava, Arthur, et al. (1987).

The first objective for drilling in the Labrador Sea was to sample the basement rock to get an estimate of the date of the magnetic anomaly sequence, thereby resolving much of the uncertainty in the record of seafloor spreading in this region. Basement cannot be reached easily in most of the Labrador Sea because of a substantial sediment cover. Site 647 in the southern Labrador Sea (Fig. 1) was chosen because of a thin section of Neogene and Paleogene sediments. Another reason for selecting this site location was that it lies near enough to the CharlieGibbs Fracture Zone, where maximum effects from the incursions of waters from the North Atlantic, the Norwegian-Greenland Sea, and the Arctic Ocean are thought to have taken place. We expected that the study of sedimentary column here would provide valuable information about paleocirculation through this region. Another site, 646, southwest of Greenland (Fig. 1) was chosen because it lies in a region where the maximum effect of the Norwegian Sea Overflow Water (NSOW) was expected, and because the top of the older Paleogene section lies at a shallow depth. Thus, this site was an ideal place for studying the onset of deep, cold, bottom-water currents in the North Atlantic.

As in the Labrador Sea, sediment thicknesses in most parts of Baffin Bay exceed $5 \mathrm{~km}$, thereby rendering the basement inaccessible to drilling. Thus Site 645 , on the western margin of Baffin bay, off the southwest coast of Baffin Island (Fig. 1), was chosen where syn-rift and early post-rift sediments lie at subbottom depths of less than $2000 \mathrm{~m}$. We hoped that drilling into these sediments would provide the age and subsidence history of early post-rift sediments, which are important for deciphering the tectonic history of this region as well as its paleocirculation.

\section{DATA COLLECTION METHODS}

Figure 2 shows the ships' track lines, along which detailed measurements were made during the cruise to the Labrador Sea. Navigation during this cruise and another cruise to Baffin Bay was maintained using the Bedford Institute of Oceanography Integrated Navigation System (BIONAV), consisting of an Austron 5000 passive ranging LORAN-C system, a Marconi CMA 72 transit doppler satellite receiver, and the ship's log and gyrocompass integrated through an HP2l-E computer. 


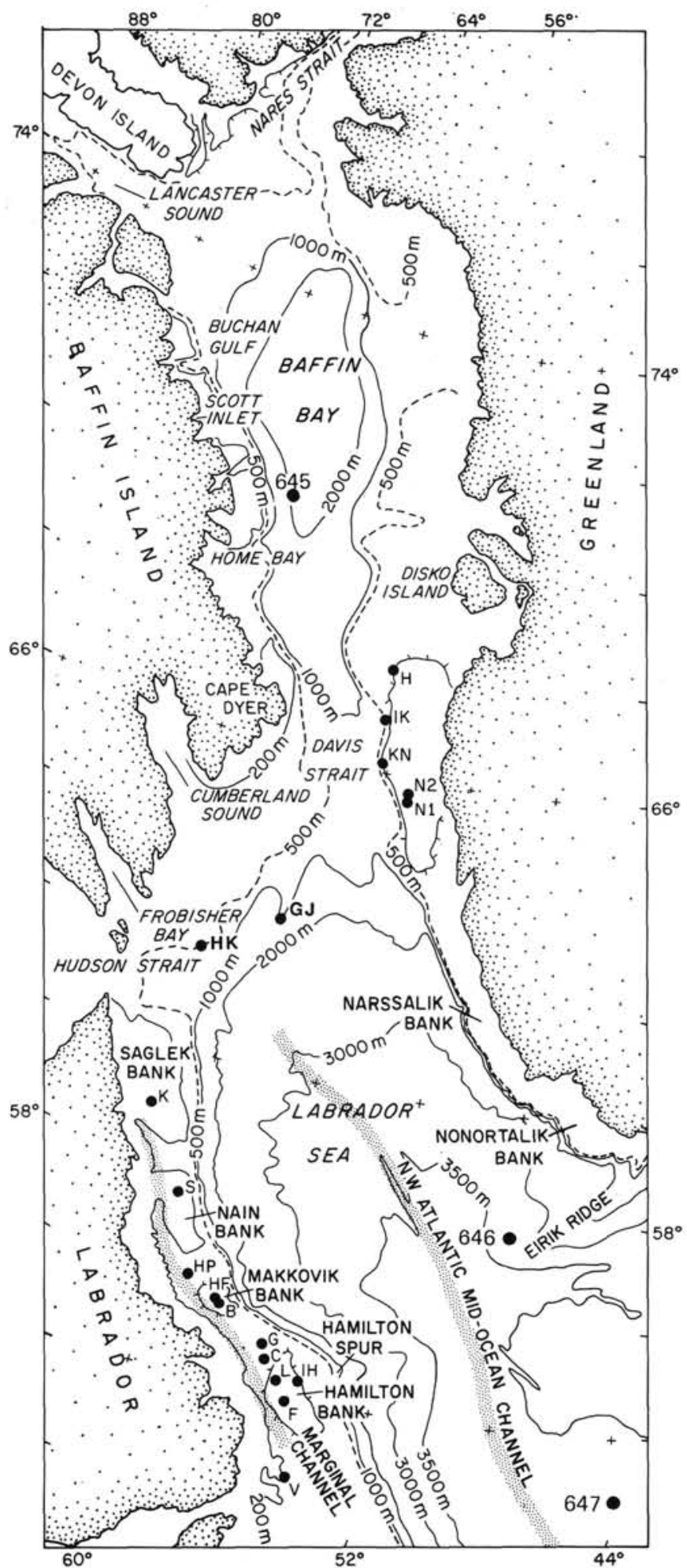

Figure 1. Generalized bathymetry of the Labrador Sea-Baffin Bay region, showing exploratory wells and ODP Sites 645,646 , and 647 , drilled during Leg 105. Karlsefni (K), Snorri (S), Hopedale (HP), Herjolf (He), Bjarni (B), Gudrid (G), Cartier (C), Lief (L), Indian Harbour (IH), Freydis (F), Verrazano (V), Nukikl (N1), Nukik2 (N2), Kangamiut (KN), Ikermiut (IK), Hellefisk (H), Hekja (HK), Gjoa (GJ) are industry exploratory wells.
The Labrador Sea LORAN-C chain was the primary source of navigation and provided excellent results. Through comparison with the satellite passes, an overall accuracy of $70 \mathrm{~m}$ or better was obtained for most regions during the survey, except near Site 646, where the transmitting station geometry reduced the accuracy to about $150 \mathrm{~m}$. A brief description follows of the methods used to measure different values.

\section{Seismic-Reflection Data}

Deep-penetration seismic-reflection measurements were performed using a single-channel Teledyne seismic streamer and a three-channel hydrophone streamer. For sound source we used a combination of an air gun $\left(1000\right.$ in. $\left.^{3}\right)$ and a water gun $\left(80\right.$ in. $\left.^{3}\right)$ fired together at a rate of once every $15 \mathrm{~s}$. The signals from the two streamers were recorded digitally using a DFS-IV system and in analog form on FM tapes. For the Baffin Bay survey high-resolution data was collected using a single-channel 100 -ft streamer and a 40 -in. ${ }^{3}$ air gun. In both instances the signals were displayed in analog form on a Raytheon recorder after being filtered and amplified through time-varying amplifiers. A network of survey lines was run at each site. Seismic data were recorded along with other parameters. The lines were designed so that they would adequately map each site and provide a number of crossings with pre-existing lines through these regions.

Shallow-penetration, high-resolution seismic data were obtained using a $3.5-\mathrm{kHz}$ ORE sounding system that was towed amidships on the port side at a depth of 10 to $20 \mathrm{ft}$. To obtain detailed reflection information of the top 200-m sedimentary section at each site, a 40 -in. ${ }^{3}$ air gun was used instead of a 1000 -in. ${ }^{3}$ gun. Seismic measurements throughout the cruises were conducted at a ship speed of 5 to $6 \mathrm{kt}$.

\section{Seismic-Refraction Data}

Wide-angle reflection and refraction arrivals were recorded at Site 646 using Fairfield expendable sonobuoys. These measurements were performed by dropping the sonobuoy in water astern of the ship and then steaming away from it and firing a 2000 -in. ${ }^{3}$ air gun. The signals from the sonobuoy were monitored on an $X-Y$ plotter and recorded on FM tape. For the Site 647 survey, the sonobuoys malfunctioned and no velocity information was obtained. No velocity measurements were performed at Site 645 .

\section{Gravity, Magnetic, and Bathymetry Data}

Variations in the gravity field were recorded throughout the cruise using a BSW KSS-30 model gravimeter mounted on a gyro-stabilized platform. In regions having good navigation control we were able to measure gravity with an accuracy of $1.0 \mathrm{mgal}$, while in regions of poor navigation control an accuracy of 2 to $3 \mathrm{mgal}$ was achieved.

Total magnetic field values were recorded using a Barringer Proton Precession magnetometer system. The sensor was towed $233 \mathrm{~m}$ astern of the ship and the output from the system was recorded on a BIO Digital Acquisition Logging System, together with day and time. Soundings during the cruise were obtained using a $12.0-\mathrm{kHz}$ transducer mounted on a retractable ram under the ship's hull.

\section{Heat-Flow Data}

Heat flow was measured at the two sites in the Labrador Sea to assess their geothermal characteristics, as well as for comparison with subsequent downhole measurements conducted during Leg 105 in this region. Two different probes were used for these measurements: one from Dalhousie University (DAL) and the other from Memorial University (MUN). Technical descriptions of these instruments are given by Hutchison and Owen (1988) and Wright and Fang (1988), respectively. Both instruments use the violin-bow design probe of Lister (as described in Hyndman et al., 1978), and can measure both thermal gradient and insitu conductivity during multiple penetration of up to 10 sensors over a length of 4 to $6 \mathrm{~m}$.

Six heat-flow measurements were conducted at Site 647 using the DAL probe, and eight at Site 646, two with the MUN probe and six with the DAL probe. All stations at Site 646 had measurements of in-situ conductivity, but only one at Site 647 . Table 1 lists their positions, with day and time, and water depths. In addition, a total of 74 needle-probe conductivity measurements (Von Herzen and Maxwell, 1959) were performed on two cores, one at each site. 


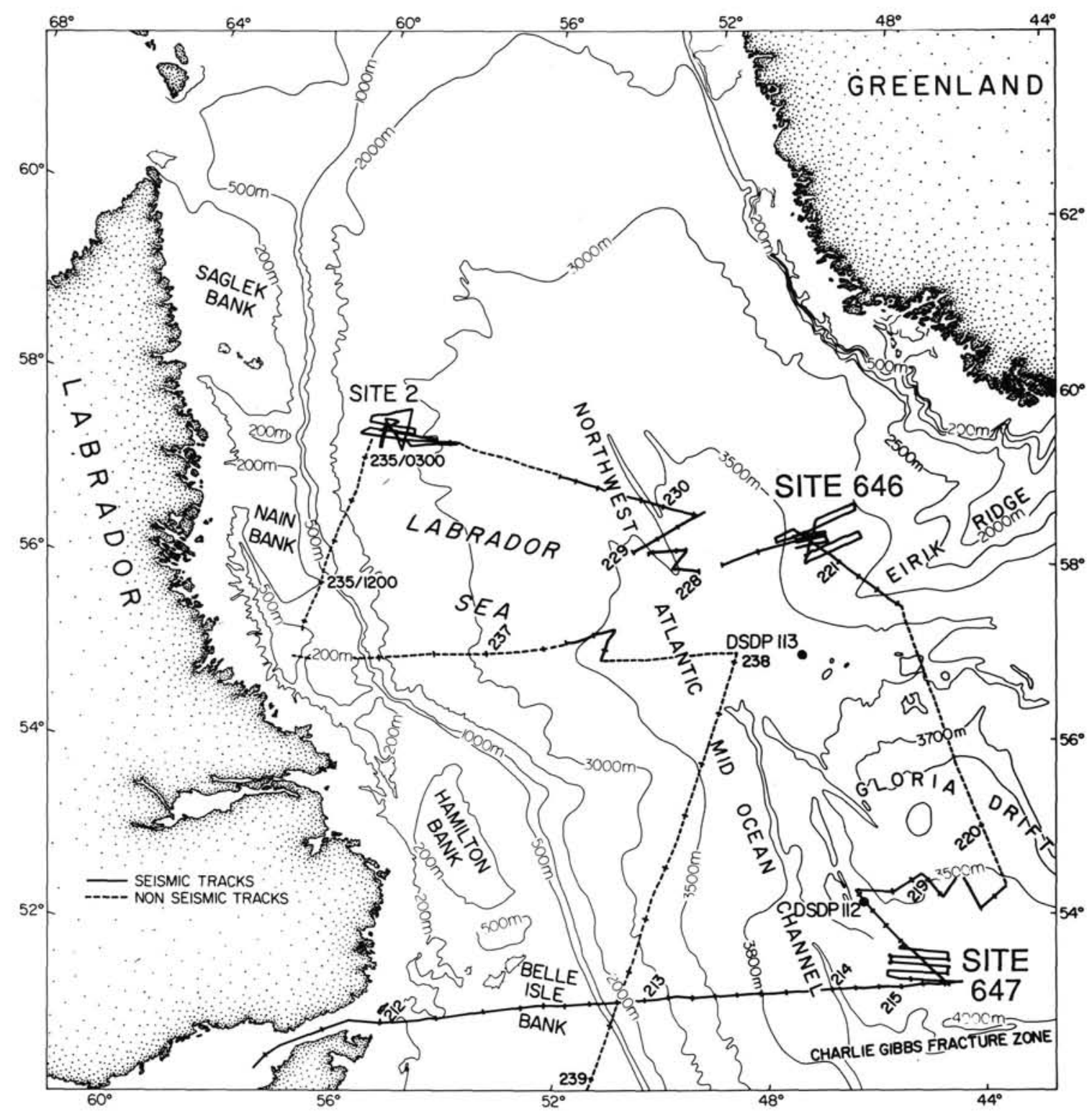

Figure 2. Ship track lines of the site-survey cruise (HU-84-30) to the Labrador Sea.

\section{Coring Data}

Three piston cores at each site were collected using a Benthos splitpiston corer coupled with a Benthos gravity corer that acted as a trigger weight. These cores were taken to assess the suitability of the sites for carrying out high-resolution Quaternary biostratigraphy, palynostratigraphy, and oxygen-isotopic studies. Table 2 lists the positions, water depths, and lengths of the cores recovered at each site, together with day and time.

\section{RESULTS}

\section{Site 647}

Figure 3 shows the track lines along which gravity, magnetic, bathymetry, and seismic-reflection measurements were performed at this site.

\section{Seismic Data}

The seismic data acquired during this survey are of excellent quality. All analog and digitally recorded data were reprocessed during and after the cruise. Copies of these records are included in the Appendix. Figure 4 shows a composite diagram of the analog records at this site. These records have been aligned in a north-south direction according to their positions, as shown in Figure 3. Several features can be easily seen in this diagram, as follows:

1. Numerous closely spaced reflectors, signifying thin, flatlying sediment layers, occur in the southwest corner of the map area. The character of these reflectors suggests that these could be turbidite flows originating from the North Atlantic MidOcean Channel (NAMOC), west of the site. They form the uppermost sediment layer in this region. To the north of and near Site 647 these beds do not show the same characteristics. There, the upper unit shows the presence of a few continuous to discontinuous reflectors. The presence of mainly homogeneous sediments is also confirmed by drilling results, which indicated only minor signs of turbidites in the sediments recovered from the top unit (Srivastava, Arthur, et al., 1987). Some variation in the thickness of the sediments can be seen in the region. 
Table 1. Heat-flow stations.

\begin{tabular}{|c|c|c|c|c|c|c|}
\hline & $\begin{array}{c}\text { Day } \\
(\mathrm{GMT})\end{array}$ & $\begin{array}{l}\text { Time } \\
\text { (GMT) }\end{array}$ & $\begin{array}{c}\text { Latitude } \\
\text { ('N) }\end{array}$ & $\begin{array}{l}\text { Longitude } \\
\text { ('W) }\end{array}$ & $\begin{array}{l}\text { Depth } \\
\text { (fms) }\end{array}$ & Instrument \\
\hline \multicolumn{7}{|l|}{ Site 647} \\
\hline $9-1$ & 215 & 1641 & $53^{\circ} 22.10^{\prime}$ & $45^{\circ} 19.44^{\prime}$ & 3842 & DAL \\
\hline $9-2$ & 215 & 1735 & & & 3840 & DAL \\
\hline $9-2 \mathrm{a}$ & 215 & 1743 & $53^{\circ} 22.00^{\prime}$ & $45^{\circ} 20.12^{\prime}$ & 3840 & DAL \\
\hline $9-3$ & 217 & 1134 & $53^{\circ} 21.37^{\prime}$ & $45^{\circ} 18.74^{\prime}$ & 3826 & DAL \\
\hline $9-4$ & 217 & 1245 & $53^{\circ} 22.34^{\prime}$ & $45^{\circ} 17.68^{\prime}$ & 3810 & DAL \\
\hline $9-5$ & 217 & 1344 & $53^{\circ} 22.27^{\prime}$ & $45^{\circ} 17.42^{\prime}$ & 3808 & DAL \\
\hline $9-6$ & 217 & 1502 & $53^{\circ} 23.36^{\prime}$ & $45^{\circ} 16.00^{\prime}$ & 3796 & DAL \\
\hline $9-7$ & 217 & 1626 & $53^{\circ} 24.14^{\prime}$ & $45^{\circ} 13.11^{\prime}$ & - & DAL \\
\hline $9-7 a$ & 217 & 1648 & $53^{\circ} 24.05^{\prime}$ & $45^{\circ} 13.33^{\prime}$ & 3791 & DAL \\
\hline \multicolumn{7}{|l|}{ Site 646} \\
\hline $5-1$ & 223 & & $58^{\circ} 00.84^{\prime}$ & $48^{\circ} 23.36^{\prime}$ & 1797 & MUN \\
\hline $5-2$ & 223 & & $58^{\circ} 03.73^{\prime}$ & $48^{\circ} 21.92^{\prime}$ & - & MUN \\
\hline $5-3$ & 226 & 2118 & $58^{\circ} 05.20^{\prime}$ & $48^{\circ} 25.95^{\prime}$ & 1826 & DAL \\
\hline $5-4$ & 226 & 2240 & $58^{\circ} 05.52^{\prime}$ & $48^{\circ} 24.15^{\prime}$ & 1827 & DAL \\
\hline $5-5$ & 226 & 2342 & $58^{\circ} 05.50^{\prime}$ & $48^{\circ} 23.60^{\prime}$ & 1827 & DAL \\
\hline $5-6$ & 227 & 0101 & $58^{\circ} 05.43^{\prime}$ & $48^{\circ} 22.33^{\prime}$ & 1825 & DAL \\
\hline $5-7$ & 227 & 0215 & $58^{\circ} 05.25^{\prime}$ & $48^{\circ} 21.02^{\prime}$ & 1825 & DAL \\
\hline $5-8$ & 227 & 0345 & $58^{\circ} 04.77^{\prime}$ & $48^{\circ} 20.23^{\prime}$ & 1820 & DAL \\
\hline
\end{tabular}

Table 2. Sediment cores obtained near each of the ODP sites studied.

\begin{tabular}{|c|c|c|c|c|c|c|}
\hline \multirow[b]{2}{*}{ Cruise } & \multirow{2}{*}{$\begin{array}{c}\text { Core } \\
\text { no. }\end{array}$} & \multicolumn{2}{|c|}{$\begin{array}{c}\text { Core } \\
\text { length }(m)\end{array}$} & \multirow[b]{2}{*}{ Position } & \multirow{2}{*}{$\begin{array}{c}\text { Water } \\
\text { depth } \\
\text { (m) }\end{array}$} & \multirow[b]{2}{*}{ Time } \\
\hline & & TWC & PC & & & \\
\hline $84-030$ & $9 \mathrm{C}-1$ & 1.53 & 8.58 & $\begin{array}{l}53^{\circ} 19.75^{\prime} \mathrm{N} \\
45^{\circ} 18.54^{\prime} \mathrm{W}\end{array}$ & 3782 & $215 / 1749$ \\
\hline $84-030$ & $9 \mathrm{C}-2$ & 2.07 & 7.80 & $\begin{array}{l}53^{\circ} 19.42^{\prime} \mathrm{N} \\
45^{\circ} 16.23^{\prime} \mathrm{W}\end{array}$ & 3781 & $217 / 1506$ \\
\hline $84-30$ & $9 \mathrm{C}-3$ & 1.89 & 10.47 & $\begin{array}{l}53^{\circ} 19.79^{\prime} \mathrm{N} \\
45^{\circ} 15.85, \mathrm{~W}\end{array}$ & 3771 & $218 / 0223$ \\
\hline $84-30$ & $5 C-1$ & 1.97 & 5.25 & $\begin{array}{l}58^{\circ} 04.07^{\prime} \mathrm{N} \\
48^{\circ} 23.64^{\prime} \mathrm{W}\end{array}$ & 3323 & $223 / 1242$ \\
\hline $84-30$ & $5 \mathrm{C}-2$ & 0.66 & 11.20 & $\begin{array}{l}58^{\circ} 04.28^{\prime} \mathrm{N} \\
48^{\circ} 23.60^{\prime} \mathrm{W}\end{array}$ & 3326 & $223 / 1538$ \\
\hline $84-30$ & $5 \mathrm{C}-3$ & 0.67 & 9.85 & $\begin{array}{l}58^{\circ} 04.60^{\prime} \mathrm{N} \\
48^{\circ} 54.69^{\prime} \mathrm{W}\end{array}$ & 3430 & $226 / 1251$ \\
\hline $85-27$ & 5 & 1.50 & 6.18 & $\begin{array}{l}70^{\circ} 29.45^{\prime} \mathrm{N} \\
64^{\circ} 39.45^{\prime} \mathrm{W}\end{array}$ & 2029 & $270 / 1029$ \\
\hline $85-27$ & 6 & Box Cc & & $\begin{array}{l}70^{\circ} 29.37^{\prime} \mathrm{N} \\
64^{\circ} 41.06^{\prime} \mathrm{W}\end{array}$ & 2029 & $270 / 1235$ \\
\hline $85-27$ & 7 & 1.50 & 6.12 & $\begin{array}{l}70^{\circ} 29.67^{\prime} \mathrm{N} \\
64^{\circ} 42.02^{\prime} \mathrm{W}\end{array}$ & 2029 & $270 / 1422$ \\
\hline $85-27$ & 9 & Box Co & & $\begin{array}{l}70^{\circ} 33.70^{\prime} \mathrm{N} \\
63^{\circ} 11.28^{\prime} \mathrm{W}\end{array}$ & 2100 & $270 / 1922$ \\
\hline $85-27$ & 16 & 1.63 & 6.12 & $\begin{array}{l}70^{\circ} 30.78^{\prime} \mathrm{N} \\
64^{\circ} 31.24^{\prime} \mathrm{W}\end{array}$ & 2091 & $272 / 1431$ \\
\hline $85-27$ & 17 & 1.51 & 4.86 & $\begin{array}{l}70^{\circ} 30.71^{\prime} \mathrm{N} \\
64^{\circ} 30.57^{\prime} \mathrm{W}\end{array}$ & 2092 & $272 / 1645$ \\
\hline
\end{tabular}

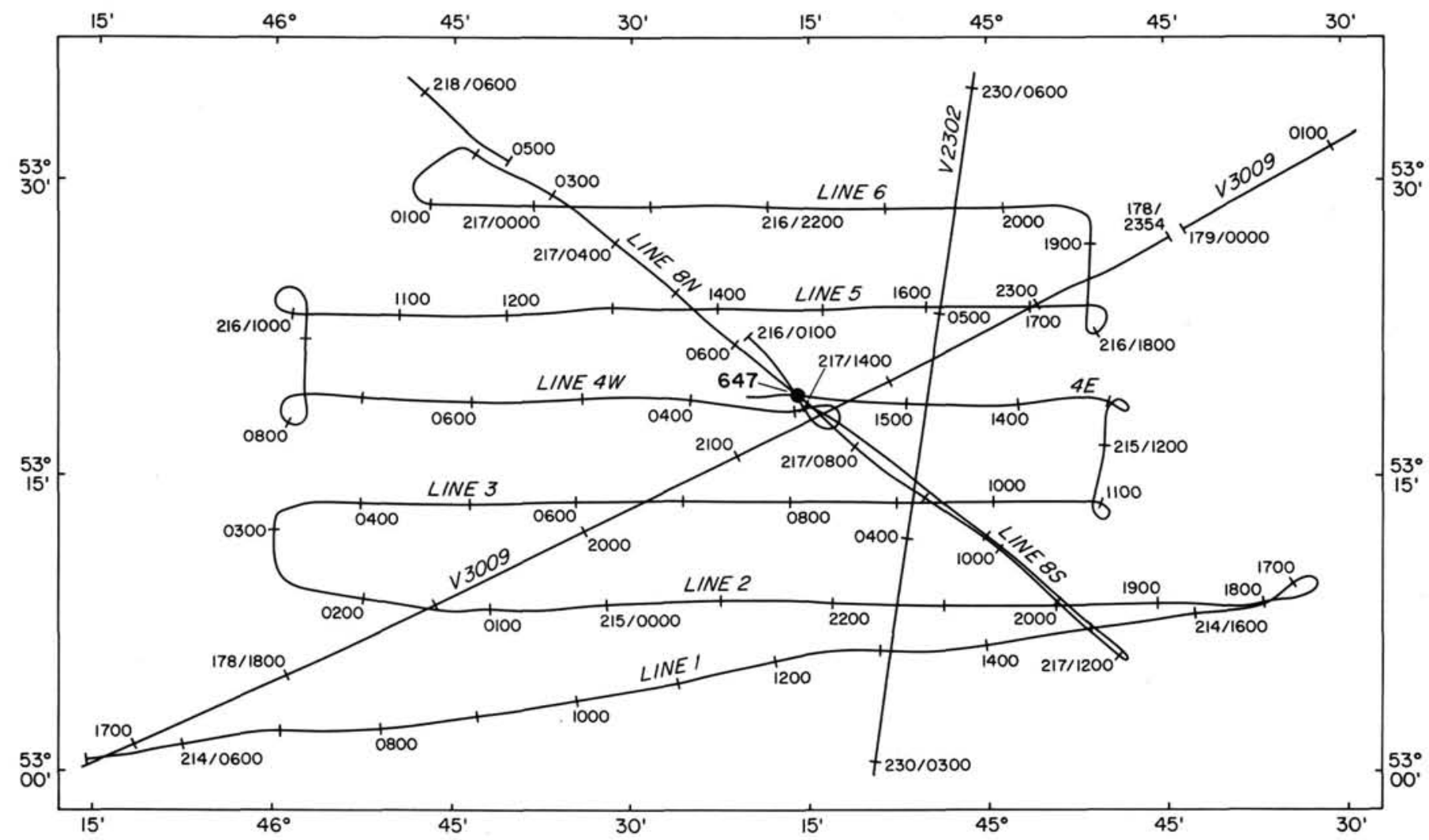

Figure 3. Map showing the location of ship track lines, with day and time, near Site 647 along which gravity, magnetic, bathymetry, and seismic data were collected during a detailed survey. Additional seismic lines through the region are also shown (number referred to in the text). 

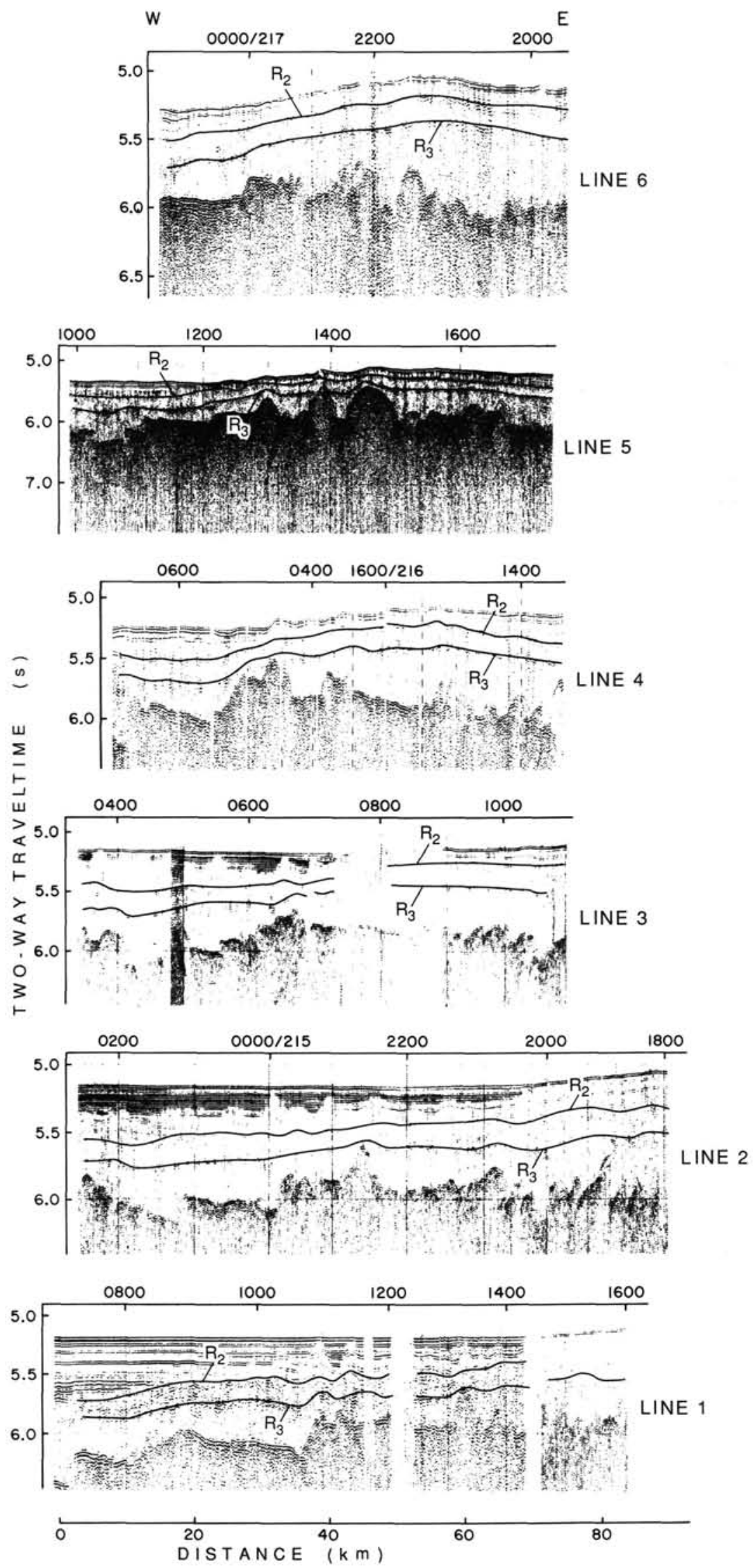

Figure 4. A composite diagram of most of the seismic data collected in the vicinity of Site 647 . The seismic lines have been aligned vertically according to their position shown in Figure 3. 
2. A prominent reflector, called here $\mathrm{R} 2$, occurs near the site about $0.15 \mathrm{~s}$ below the seafloor. The same reflector can be seen on regional profiles and forms a prominent unconformity in the southern profiles. Drilling results at Site 647 show that this seismic event coincides with two major hiatuses, at 2.5 to $5.6 \mathrm{Ma}$ and at 8.2 to $17.5 \mathrm{Ma}$, separated by $3 \mathrm{~m}$ of sediments (Srivastava, Arthur, et al., 1987).

3. Below reflector R2 the seismic records show the presence of a transparent layer below which lies another prominent refector, called here R3. This reflector is similar to one drilled at DSDP Site 112 northwest of Site 647 (Fig. 2). This was correlated by Miller and Tucholke (1983) with a prominent reflector drilled on the eastern side of the Atlantic, interpreted to mark the onset of vigorous deep bottom currents near the Eocene/ Oligocene boundary. Drilling results at Site 647 show that this reflector is associated with lithologic changes from mainly siliceous sediments overlying calcareous sediments (Srivastava, Arthur, et al., 1987). Depths to this reflector are somewhat variable.

4. Seismic lines south and west of the Site 647, for example lines 1,2 , and 3 , indicate piercement structures where the records show some opaqueness. This is clearly illustrated in Figure 5 , where a corresponding section of a $3.5-\mathrm{kHz}$ record is also shown. The refectors within the structure are pulled up. We are not certain what caused this structure but most likely it results from the excess biogenic gas generated within the top layers. Drilling results failed to show the presence of any excess gas at the site. The structures exist only in regions where the turbidite layers are not excessively thick. For example, in Figure 25, we do not see these structures at the western end of the section as we approach the NAMOC.

5. Some variations in the basement topography can be seen from the stacked profiles (Fig. 4). To see if these variations are in some way related to the shift in the ridge axis soon after anomaly 25 time in this region (Srivastava, 1978), we restacked these profiles along a boundary that we believe marks a change in the basement morphology (Fig. 6). The basement to the west of this line shows a smoother topography than to the east. This is perhaps caused by a jump in the ridge axis to the east soon after anomaly 25 time, thereby creating an age difference across this boundary. The crust would then decrease in age on both sides of this boundary. The exact difference in ages of the crust segments on either side of this boundary would depend on the exact time of the ridge jump, as well as on the distance between the old and new positions of the ridge axis. We will return to this point when discussing the magnetic anomalies in this region. Copies of all seismic data collected at this site are given in the Appendix.

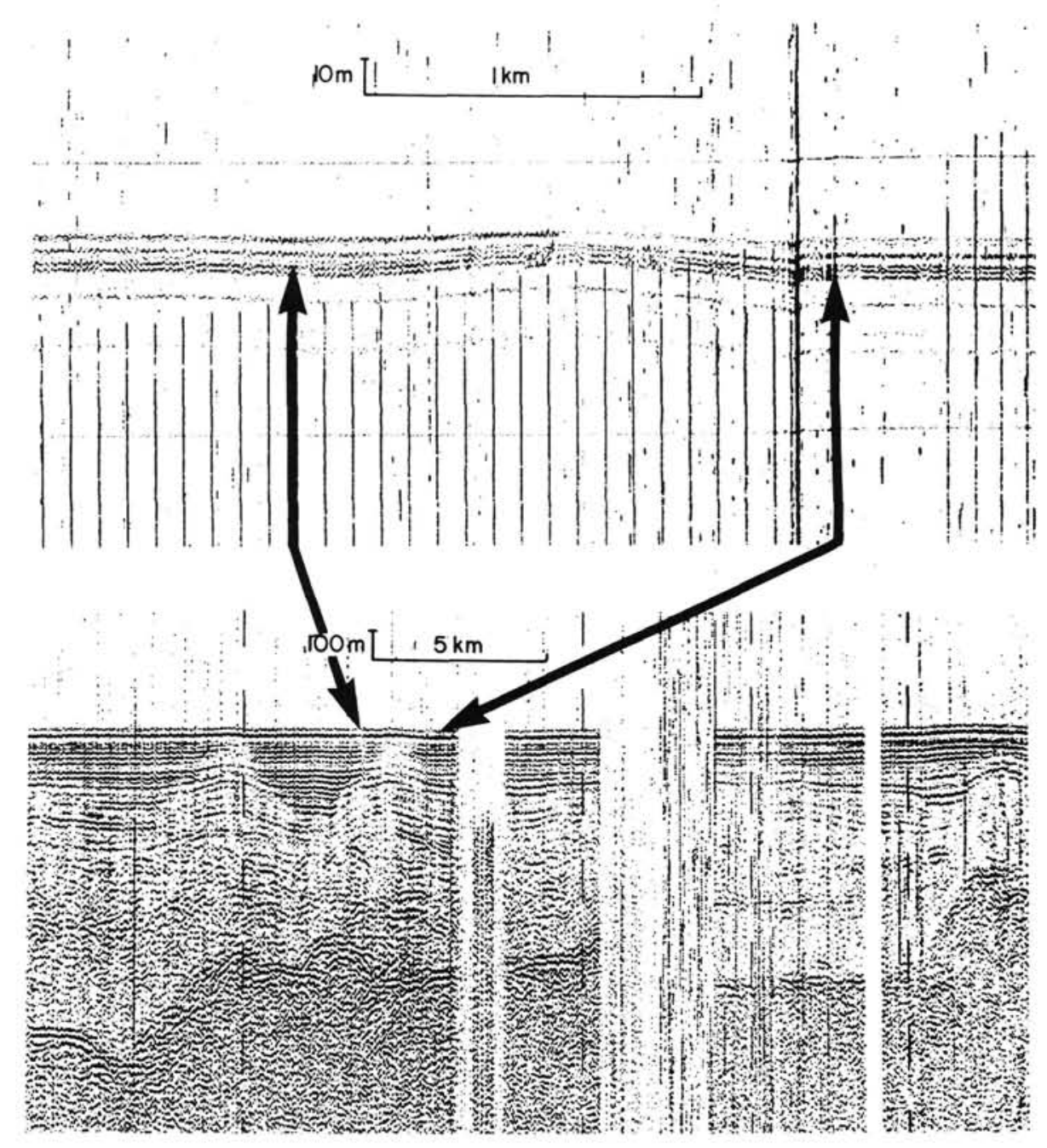

Figure 5. A section of a seismic line (bottom) and $3.5-\mathrm{kHz}$ sounding record (top) showing the piercement structure south of Site 647. 

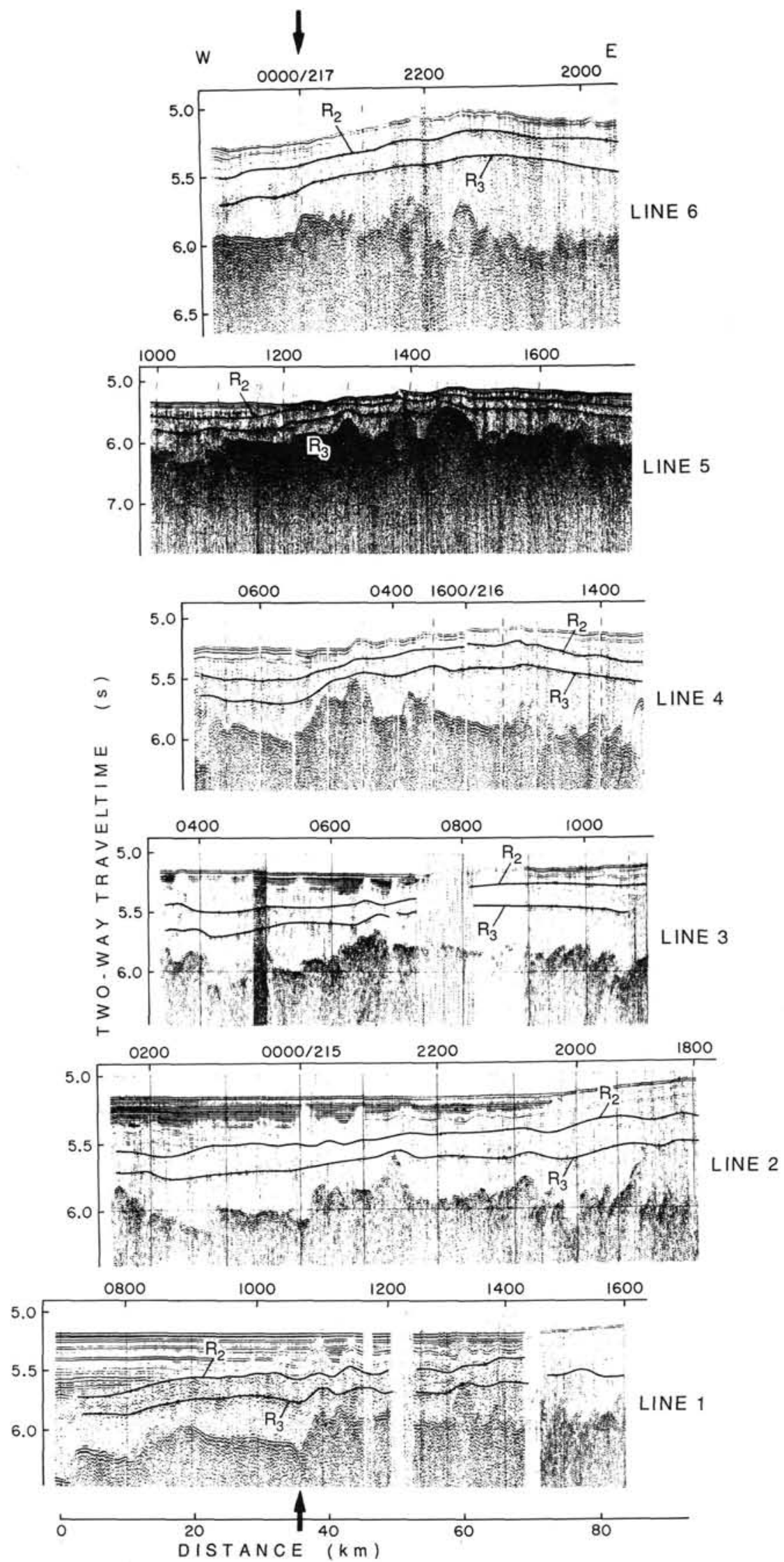

Figure 6. Seismic profiles stacked along a line (marked by arrows) showing a change in the basement character from smooth to rough. The position of this line is also shown in Figure 9. 


\section{S. P. SRIVASTAVA ET AL.}

We were unable to obtain velocity values for the sediments overlying the basement in this region because the sonobuoys malfunctioned.

\section{Echo Characteristics}

The high-resolution bathymetry data recorded using the 3.5$\mathrm{kHz}$ system was analyzed at this site to determine the acoustic characteristics of the sea bed, essentially following the scheme of Damouth (1980), and were interpreted in terms of sedimentary processes. Results from this study have been published separately by Chough et al. (1985) and only a brief description is included here for the sake of continuity. Table 3 summarizes the classification that was followed for describing the echo characteristics, and these are illustrated in Figure 7.
Only two types of echoes, type IB-4 and IB-1, were observed in the region of Site 647 (Fig. 8), which lies on the southern flank of the Gloria Drift (Fig. 2). Continuous sharp bottom echoes with several shallow (less than about $10 \mathrm{~m}$ ) continuous parallel sub-bottom reflectors (type IB-4) prevail throughout this region. In some of the crossings of the southern part of the Gloria Drift the echo characteristics remain similar to those of the basin plain, except for some large sediment waves of up to a few kilometers in wave length. On seismic records these features are seen as large-scale climbing dunes (Fig. 32 at $30 \mathrm{~km}$ ). Sub-bottom reflectors in these dunes tend to become thicker toward the trough, suggestive of bottom current winnowing. They are often accompanied by intermittent, discontinuous sub-bottom echoes in the trough. The bottom echoes sometimes form a transparent

Table 3. Echo types.

\begin{tabular}{|c|c|c|c|c|c|c|c|}
\hline & $\begin{array}{l}\text { Damuth } \\
(1980)\end{array}$ & $\begin{array}{l}\text { This } \\
\text { cruise }\end{array}$ & Line Drawing & $\begin{array}{l}\text { Type } \\
\text { Section }\end{array}$ & Description & Occurrence & Interpretation \\
\hline \multirow{6}{*}{ 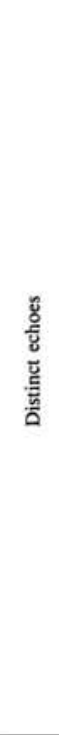 } & IA & IA & & $\begin{array}{l}228 / 0439- \\
228 / 0459\end{array}$ & $\begin{array}{l}\text { Continuous, sharp bottom } \\
\text { echoes with no } \\
\text { subbottom reflectors. }\end{array}$ & $\begin{array}{l}\text { NAMOC floor } \\
\text { Continental slope and rise } \\
\text { Belle Isle Bank }\end{array}$ & Turbidity current scour; winnowed lag \\
\hline & \multirow[t]{4}{*}{ IB } & IB-1 & & $\begin{array}{l}214 / 0939- \\
214 / 0959\end{array}$ & $\begin{array}{l}\text { Continuous, sharp bottom } \\
\text { echoes with many } \\
\text { continuous, sharp, } \\
\text { parallel subbotom } \\
\text { reflectors. } \\
\end{array}$ & $\begin{array}{l}\text { Natural levees of } \\
\text { NAMOC; basin plain }\end{array}$ & Turbidity current overspill \\
\hline & & IB-2 & & $\begin{array}{l}213 / 0700 \\
213 / 0720\end{array}$ & $\begin{array}{l}\text { Continuous, sharp bottom } \\
\text { echoes, with many } \\
\text { subparallel subbottom } \\
\text { reflectors on a rolling } \\
\text { topography. }\end{array}$ & $\begin{array}{l}\text { Lower continential slope } \\
\text { and rise }\end{array}$ & Bottom current \\
\hline & & IB-3 & & & $\begin{array}{l}\text { Continuous, sharp bottom } \\
\text { echoes with numerous } \\
\text { wedging subbottom } \\
\text { reflectors (dunes). }\end{array}$ & $\begin{array}{l}\text { Continental slope; Gloria } \\
\text { Drift and Eirik Ridge }\end{array}$ & Bottom current \\
\hline & & IB-4 & & $\begin{array}{l}214 / 1639- \\
214 / 1659\end{array}$ & $\begin{array}{l}\text { Continuous, sharp bottom } \\
\text { echoes with only } \\
\text { several parallel } \\
\text { continuous } \\
\text { discontinuous } \\
\text { subbottom reflectors } \\
\text { on a flat to gently } \\
\text { rolling topography. } \\
\end{array}$ & $\begin{array}{l}\text { Basin plain, Gloria Drift, } \\
\text { Erik Ridge }\end{array}$ & $\begin{array}{l}\text { (Hemi)pelagic settling and bottom } \\
\text { current winnowing }\end{array}$ \\
\hline & IC & IC & & $\begin{array}{l}228 / 0550- \\
228 / 0600\end{array}$ & $\begin{array}{l}\text { Continuous, sharp bottom } \\
\text { echoes, with one or } \\
\text { two sharp } \\
\text { unconformable } \\
\text { wedging subbottom } \\
\text { reflectors. } \\
\end{array}$ & NAMOC floor & Turbidity current (Point bars) \\
\hline \multirow{2}{*}{ 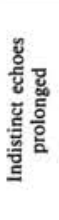 } & IIA & IIA & & $\begin{array}{l}229 / 0550 \\
229 / 0610\end{array}$ & $\begin{array}{l}\text { Semi-prolonged bottom } \\
\text { echoes with } \\
\text { intermittent zones of } \\
\text { semi-prolonged often } \\
\text { discontinuous, } \\
\text { subbottom reflectors. }\end{array}$ & Natural levees of NAMOC & Turbidity current overspill \\
\hline & IIB & IIB & & $\begin{array}{l}214 / 0049 \\
214 / 0109\end{array}$ & $\begin{array}{l}\text { Very prolonged bottom } \\
\text { echoes with no } \\
\text { subbottom reflectors. }\end{array}$ & $\begin{array}{l}\text { Belle Isle Bank, Natural } \\
\text { levee of NAMOC }\end{array}$ & Glacial moraine; proximal turbidite \\
\hline \multirow{2}{*}{ 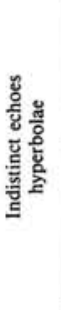 } & IIIC & IIIC & & $\begin{array}{l}212 / 1820 \\
212 / 1930\end{array}$ & $\begin{array}{l}\text { Regular, overlapping } \\
\text { hyperbolae with } \\
\text { varying vertex } \\
\text { elevations above the } \\
\text { sea floor and no } \\
\text { subbottom reflectors. }\end{array}$ & $\begin{array}{l}\text { Belle Isle Bank shelf } \\
\text { break NAMOC floor }\end{array}$ & Glacial moraine; turbidity current \\
\hline & IIID & $\begin{array}{l}\text { IIID } \\
\text { IB-3 }\end{array}$ & & $\begin{array}{l}213 / 0510 \\
213 / 0530\end{array}$ & $\begin{array}{l}\text { Broad, single, gently } \\
\text { rolling hyperbolae } \\
\text { with sharp bottom } \\
\text { echo and several } \\
\text { disconformable, } \\
\text { migrating bottom } \\
\text { reflectors. } \\
\end{array}$ & Base of slope & $\begin{array}{l}\text { Depositional lobes; weak contour } \\
\text { currents }\end{array}$ \\
\hline \multirow{2}{*}{ 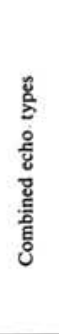 } & & IVA & & $\begin{array}{l}212 / 2050 \\
212 / 2110\end{array}$ & $\begin{array}{l}\text { Large Block-like features } \\
\text { (combined with } \\
\text { hyperbolae) reflecting } \\
\text { characteristics of } \\
\text { types IB, IIA, and } \\
\text { IIIC combined; } \\
\text { interval reflectors are } \\
\text { remanent. }\end{array}$ & $\begin{array}{l}\text { NAMOC; continental } \\
\text { slope }\end{array}$ & MASS flows \\
\hline & & IVB & & $233 / 720$ & $\begin{array}{l}\text { Distinct bottom echoes } \\
\text { with distinct } \\
\text { subbottom reflectors } \\
\text { (double IA type); } \\
\text { transparent layer in } \\
\text { between. }\end{array}$ & $\begin{array}{l}\text { Small and broad valleys } \\
\text { on the continental } \\
\text { slope }\end{array}$ & $\begin{array}{l}\text { Debris flows and winnowed sediments } \\
\text { in the slope depressions }\end{array}$ \\
\hline
\end{tabular}


A
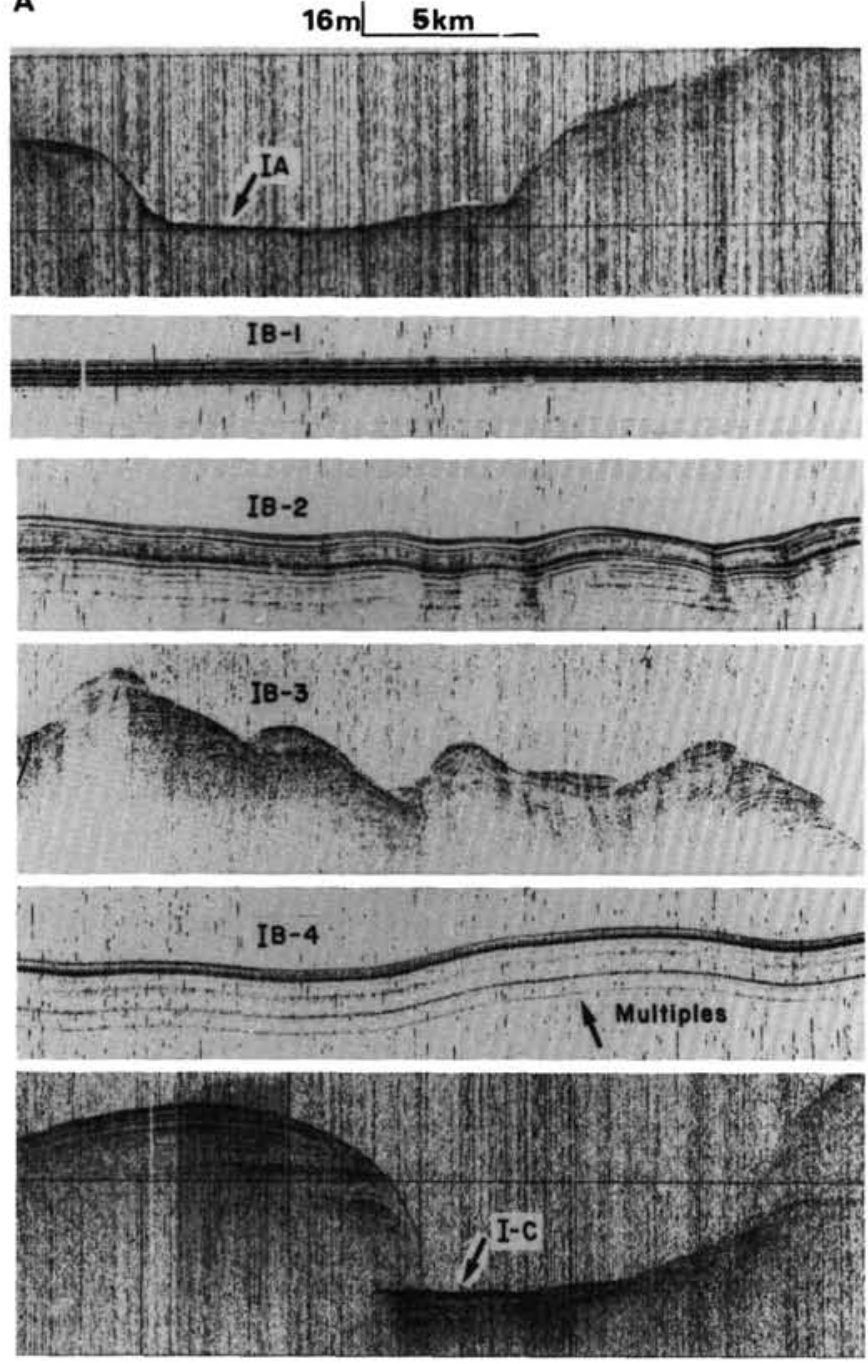

B
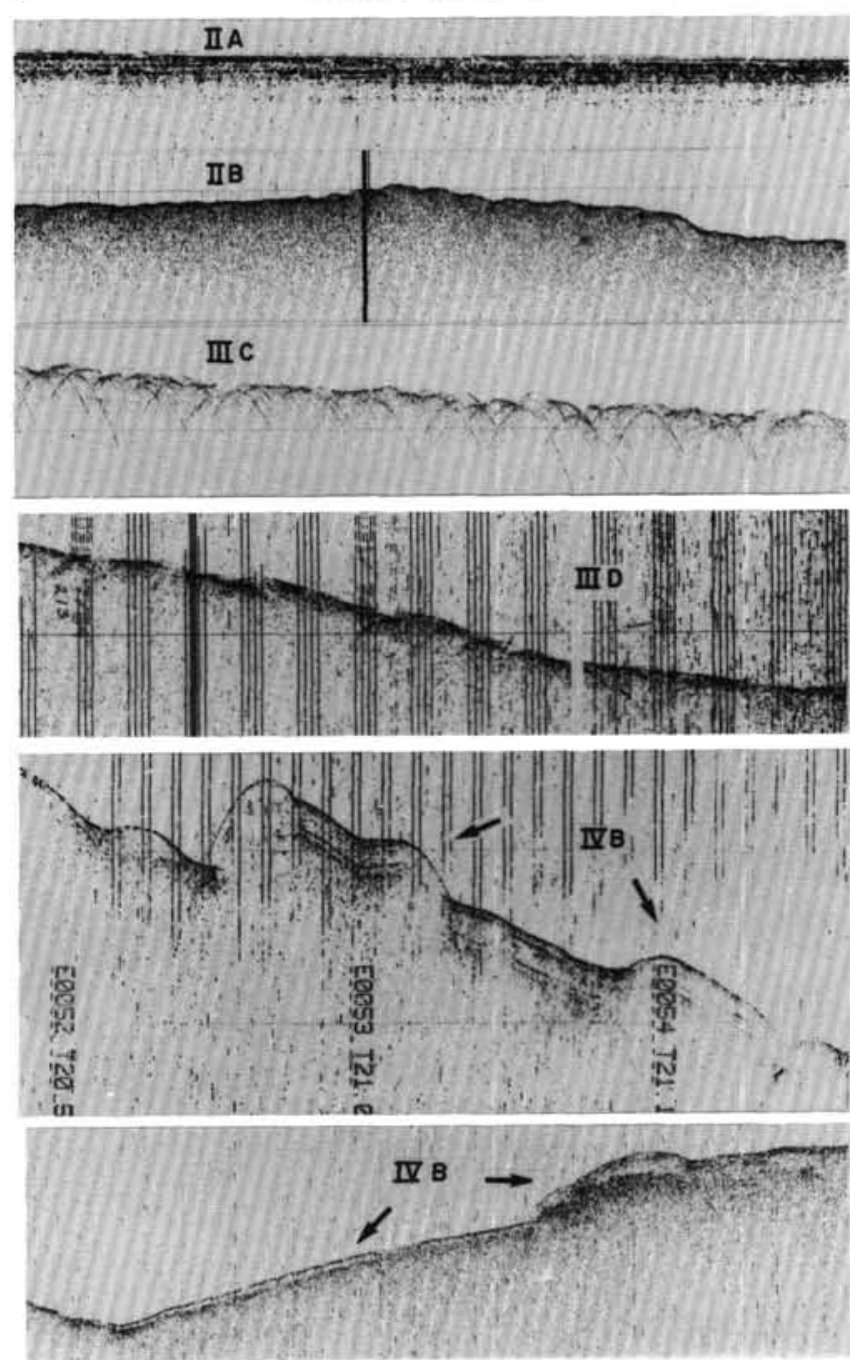

Figure 7. Examples of records from $3.5-\mathrm{kHz}$ soundings showing types of echoes observed in the Labrador Sea during the site-survey cruise.

layer having sharp continuous reflectors underlying it. The echo type IB-1, near the site, shows sharp bottom echoes having continuous sub-bottom reflectors. Some sub-bottom reflectors are gently bent upward, forming a slightly transparent bulge (Fig. 5).

\section{Magnetics and Gravity}

Figure 9 is a plot of the magnetic anomalies along the ship's track lines in the region. Anomaly 24B lies to the east of Site 647 and shows a small offset (about $5 \mathrm{~km}$ ) in the north. Anomaly $24 \mathrm{~A}$ lies slightly to the east of anomaly 24B. However, we are not certain what happens to the west of the site. This part of the area is mainly occupied by negative anomalies that show some correlation between tracks. One such correlation is shown in Figure 9 by dotted line. At a rate of spreading of $16.7 \mathrm{~mm} / \mathrm{yr}$, (obtained for this region by Srivastava et al., 1988), and considering a period of $3 \mathrm{Ma}$ between the peaks of anomalies 24B and 25 , one would expect anomaly 25 to lie about $50 \mathrm{~km}$ to the west of anomaly 24B. This would be near the eastern end of the map.

To examine the relationship of anomaly 24 , as seen near the site, with the neighboring anomalies, magnetic compilation of a much larger area was conducted (Fig. 10). Here, we see that anomaly 25 lies at a distance larger than $50 \mathrm{~km}$ to the west of the site. It also lies at an angle to anomaly 24B. The distance be- tween them increases to the north, resulting from a gradual change in the direction of spreading between them. This may have resulted in one or several jumps of the ridge axis to the east, before the formation of anomaly 24B. The dislocations in anomalies 25 and 26 observed northwest of Site 647 seem to line up with a similar dislocation in anomalies 24,23 , and 22 , suggesting the presence of a fracture zone in this region. This is substantiated by the seismic data from this region (Fig. 32 in the Appendix). However, the amount of dislocation for the anomalies decreases to the east until it disappears by anomaly 21 position. Such a gradual decrease in the dislocation across a fracture zone clearly shows propagation of one segment of the ridge against the other, until they become one continuous section.

Gravity measurements conducted along the track lines are shown in Figure 11. They show small variations in gravity field in this region, which cannot be related to the jumps in the ridge axis, as interpreted from magnetic data.

Seismic control in this region is not dense enough to document such migration of the ridge axis. However, within the detailed survey region some differences in the character of the basement are seen that could be interpreted as showing the western edge of the ridge when it jumped to the east. In Figure 6 we have stacked seismic profiles from the survey region along such 


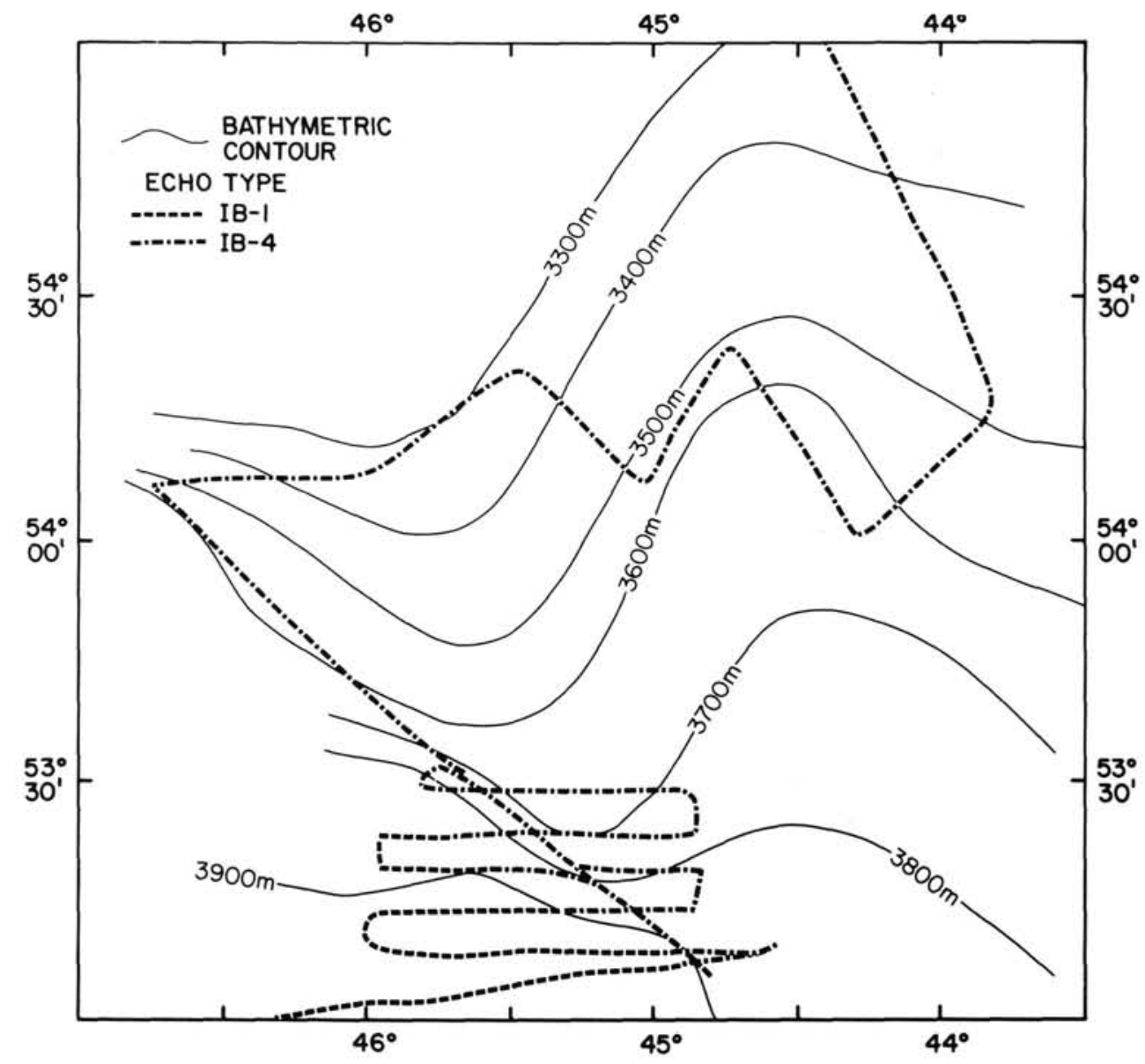

Figure 8. Map showing types of echoes observed near Site 647 .

a boundary, marking the rougher basement topography to the east and smoother topography to the west. We believe that this smoother topography is created by later volcanic flows, as shown by the flat reflectors marking the basement in this region, rather than the hummocky basement seen to the east of the boundary. To prove that this is a valid interpretation, one must consider similar anomalies from the eastern side of the Atlantic. This is beyond the scope of this study and will be dealt with elsewhere. This interpretation shows that Site 647 lies on crust that is only slightly older than anomaly 24B. However, much older crust probably lies farther to the west. This agrees well with the drilling results that show that the age of the basement under the site is about $56 \mathrm{Ma}$, as obtained from the fossiliferous sediments immediately overlying the basement (Srivastava, Arthur, et al., 1987).

\section{Heat Flow}

Six successful surface heat-flow measurements were performed near Site 647 and their positions are given in Table 1. The resulting heat-flow values are plotted as a histogram in Figure $12 \mathrm{~A}$. Only one in-situ conductivity value was obtained at this site $(0.89 \pm 0.05 \mathrm{~W} / \mathrm{m} / \mathrm{K})$, and it agrees well with the harmonic mean conductivity over the upper $4 \mathrm{~m}$ interval for Core $105-3(0.90 \pm 0.06 \mathrm{~W} / \mathrm{mK})$, as shown in Figure 13A. The mean heat-flow value, as calculated from the observations at this site, is about $73.8 \pm 3 \mathrm{~mW} / \mathrm{m}^{2}$. Based on an age of $56 \mathrm{Ma}$ for the crust at this site, the standard heat flow vs. age curves give an expected heat-flow value of $63 \mathrm{~mW} / \mathrm{m}^{2}$. This shows that the observed heat flow is slightly above normal for the region.

\section{Site 646}

Figure 14 shows the ship's track lines, along which gravity, magnetic, bathymetry, and seismic reflections were measured at this site. Other measurements performed at this site included heat-flow, coring, and seismic-refraction values.

\section{Seismic Data}

Figure 15 is a composite diagram of most of the seismic profiles collected near this site. The profiles have been stacked in a direction (shown in Fig. 14 by dotted line) that is approximately orthogonal to most of the track lines. Figure 15 shows that:

1. The entire seismic sequence above the basement in this region can be divided into a number of units signifying differences in their seismic characteristics. Such a process was followed for relating drilling results to seismic profiles (Srivastava, Arthur, et al., 1987). One can see four units have been marked on one of the profiles shown in Figure 15. Unit 1 is the uppermost unit, made up of moderate- to high-amplitude reflectors that are parallel to subparallel to the seafloor. It is thinnest over the sedimentary ridges, e.g., in lines 11,16 , and 15 . The base of this unit is marked by a prominent reflector, R1. (Numbering of reflectors at this site bears no relation to those described for Site 647.) Drilling results at Site 646 show that the position of this reflector closely corresponds to the onset of dropstones in this region. The age of this reflector is approximately $2.5 \mathrm{Ma}$ (Srivastava, Arthur, et al., 1987). Close examination of these profiles (see Appendix) shows that reflector R1 might be consid- 


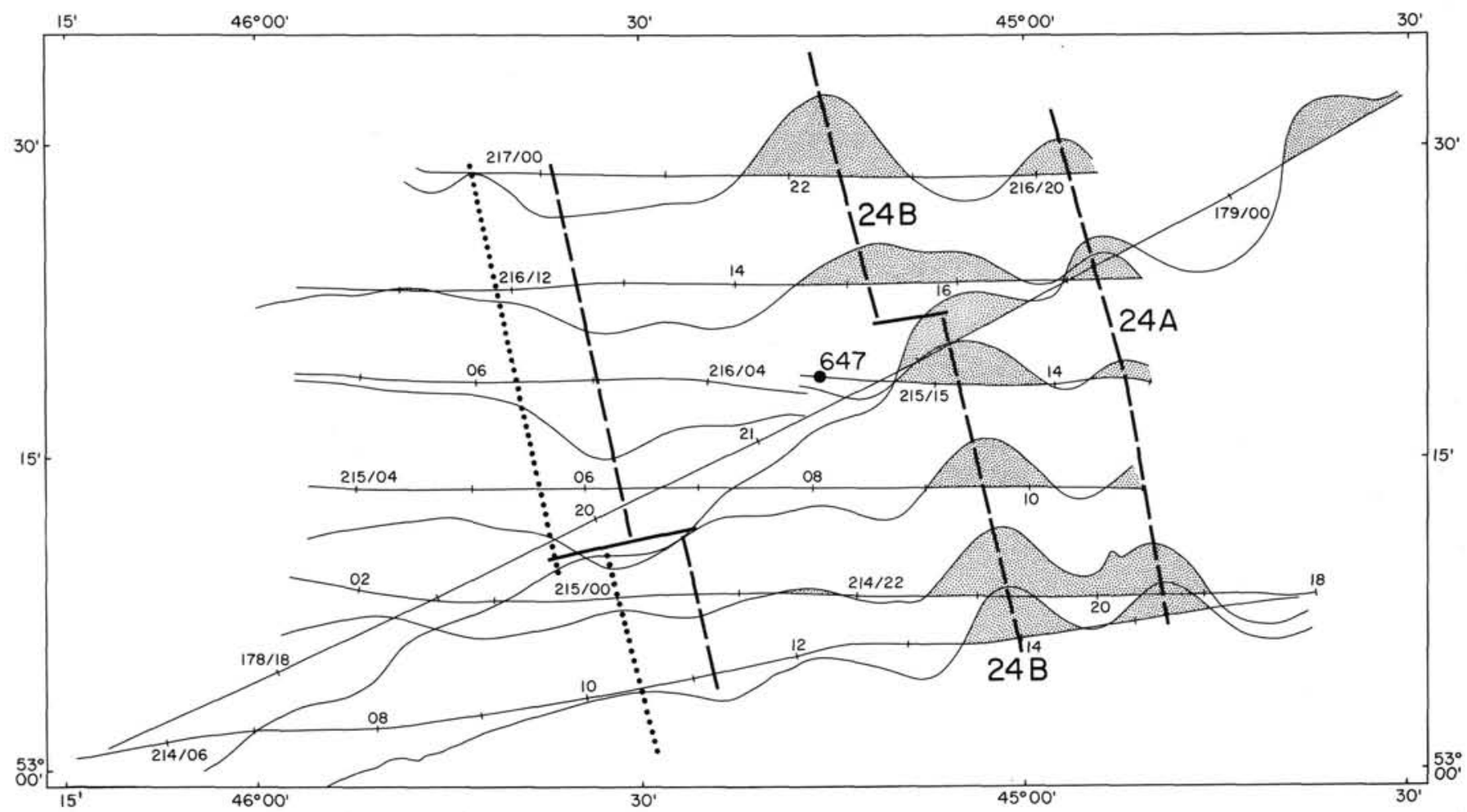

Figure 9. Magnetic anomalies plotted along track lines showing the correlation of anomalies 24A and 24B near Site 647. Also shown is a line along which seismic lines were aligned in Figure 6, marking a change in basement character from smooth to rough. The dashed lines show correlation of anomalies.

ered as an unconformity in places, as it truncates some of the layers in the underlying unit.

2. Seismic unit 2 comprises a number of high-amplitude, parallel to subparallel reflectors that resemble the style expected from a sequence of turbidites similar to that observed in the top section of unit 1 . The distance between reflectors varies somewhat in the region. At many places migrating waves suggest influence of strong bottom-water currents during the deposition of sediments in this unit. The base of this unit lies unconformably on unit 3 across most of the region. The reflectors within this unit show pronounced depositional ridges to the east. Correlation of drilling results with seismic records suggests that buildup of these depositional ridges must have occurred mainly during the early to early late Pliocene, when strata of unit 2 onlapped the slope at the top of unit 3 and progressively built a large dune that prograded northward. The increased supply of sediment together with the increased current velocity caused this episode of drift buildup.

3. Seismic unit 3 is not as distinct as the overlying unit 2 . It is somewhat transparent and in most profiles shows two reflectors. Reflector R2 lies fairly close to the top of this unit, while refector R3 forms the base. Drilling results (Srivastava, Arthur, et al., 1987) at this site show that reflector R2, which is about Pliocene/Miocene in age, is caused by a change in the carbonate content of the sediments. Carbonate-rich sediments lie above, and sediments having a variable but generally lower carbonate content lie below. Similar variations in carbonate contents are also observed across reflector R3. The age of this reflector was established as late Miocene. This reflector was correlated previously with reflector R3/R4 (Eocene/Oligocene) of the eastern Atlantic by Miller and Tucholke (1983), marking the onset of strong bottom currents in the whole of the North Atlantic.

4. Seismic unit 4 is the bottommost unit above basement. Its top is marked by reflector R3. Except for a prominent reflector
R5 near the base of this unit, no other reflectors can be seen. Reflector R5 truncates against the basement highs in most profiles. The thickness of the unit varies, as it was largely deposited over the subsiding basement, infilling the troughs and progressively onlapping and draping the basement. The sediments within this unit should range in age from early Eocene to late Miocene.

5 . Some prominent basement highs can be seen in the seismic profiles (Fig. 15). All of these highs lie to the east and south of the site (Fig. 14). If one aligns these profiles along these basement highs (Fig. 20), one finds that the highs mark a junction between the smooth and slightly rough basement topography. Except for the relief in the basement caused by these highs, the basement to the east is generally smoother than to the west of this boundary. As shown later, one finds that this is related to a major change in the directions of spreading between the two regions.

\section{Echo Characteristics}

The echo characteristics of the seafloor in the vicinity of Site 646 were compiled in the same fashion as for Site 647 , the details of which can be found in Chough et al. (1985). The echo characteristics at this site are completely dominated by type IB-4 (Fig. 4), which is characterized by sharp bottom echoes with a few weak sub-bottom reflectors forming transparent layers on a slightly rolling topography. The surface bedforms are rather smooth, with hills and mounds.

\section{Seismic-Refraction Data}

Wide-angle seismic-refraction and seismic-reflection measurements were performed at this site using expendable sonobuoys. The results from one of the sonobuoys, whose position is shown in Figure 14, are shown in Figure 16. The results show clear arrivals from a sediment layer of velocity $1.75 \mathrm{~km} / \mathrm{s}$, and a 


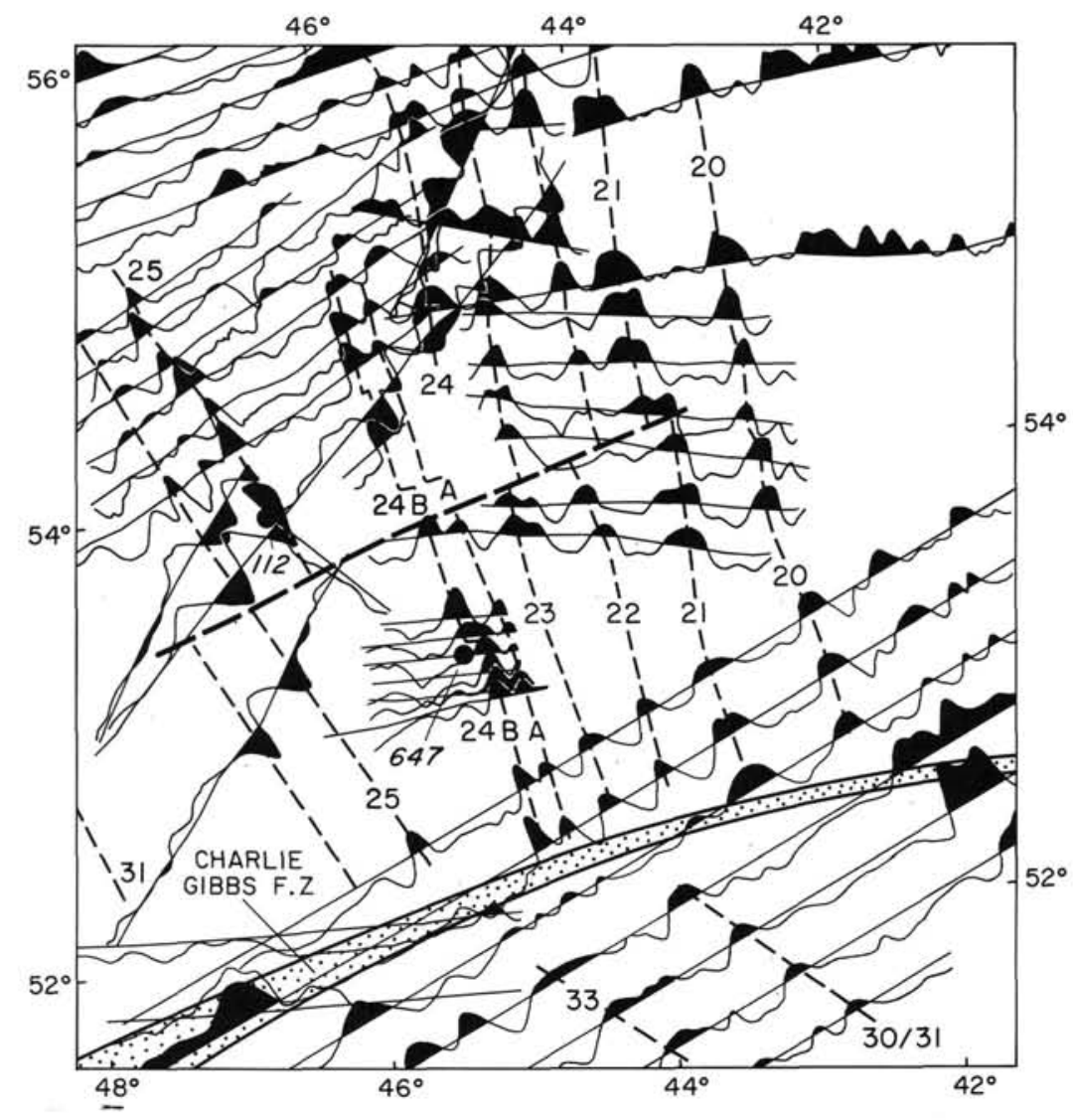

Figure 10. Magnetic anomalies plotted along track lines showing their correlations. Also shown are the Charlie-Gibbs Fracture Zone (CGFZ) and another small fracture zone north of it offseting anomalies 26 to 22 .

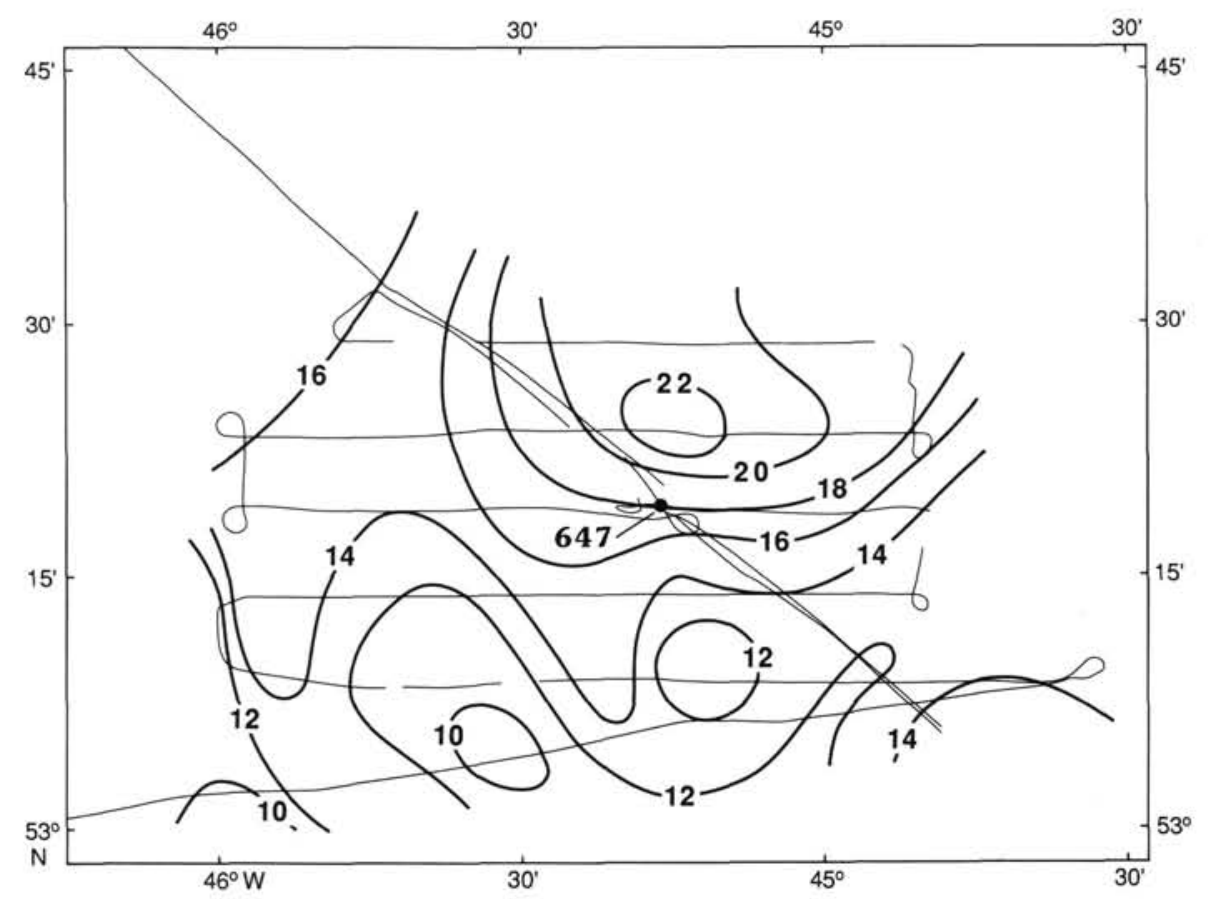

Figure 11. Free-air gravity anomalies in the vicinity of Site 647 . Contour values in mgal. 
A

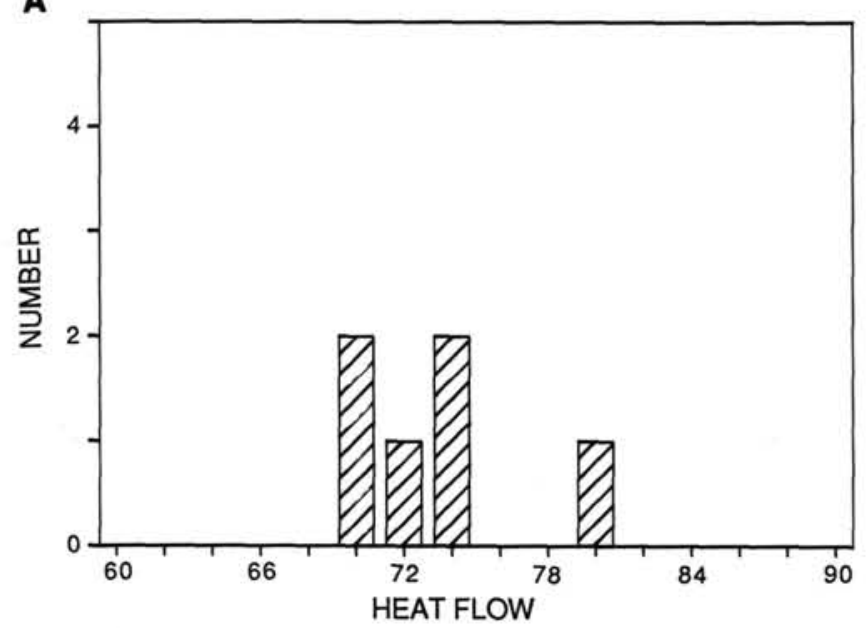

B

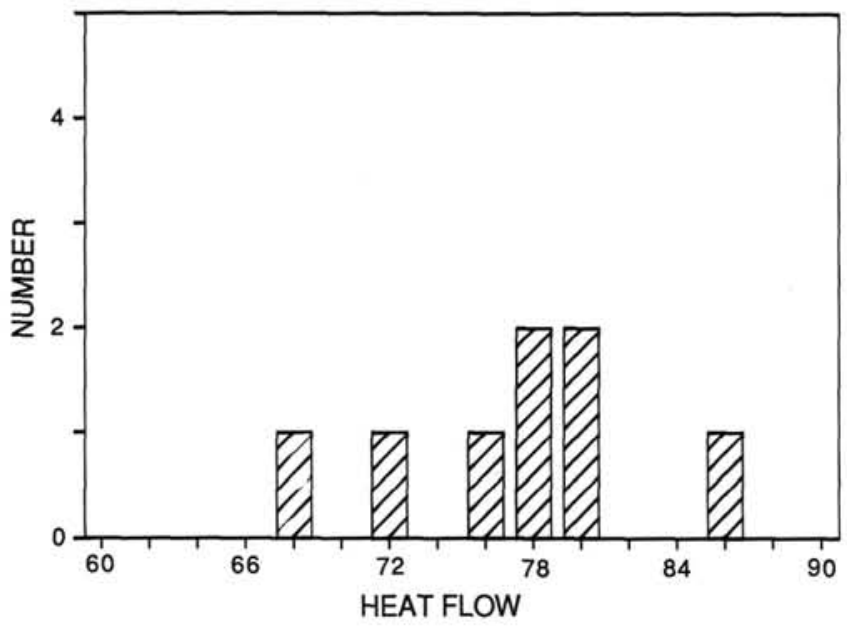

Figure 12. Histogram showing the distribution of heat-flow values obtained for A. Site 647 and B. Site 646.

high-velocity basal layer of velocity $5.1 \mathrm{~km} / \mathrm{s}$ within the oceanic crust. Also shown is the synthetic time-distance plot based on the velocity distribution shown in the figure. Note that below a velocity value of $5.1 \mathrm{~km} / \mathrm{s}$, the velocity was assumed to vary with depth to account for the observed arrivals. The highest velocity value observed here corresponds to layer 3 at a depth of $7.7 \mathrm{~km}$ from the sea surface. We do not know what the crustal thickness is in this region because we were not able to observe arrivals from the Moho.

The wide-angle reflections, as observed from these sonobuoys, were used to determine the sedimentary velocities of the overlying layers. The results are shown in Figure 17 together with the velocity distribution, as obtained by fitting the observed arrivals with the calculated velocity distribution. These calculations show velocities of 1.75 and $2.55 \mathrm{~km} / \mathrm{s}$ for the top two layers, as shown in Figure 16.

\section{Heat Flow}

Heat flow was also measured near Site 646, at locations given in Table 1. Altogether, eight heat-flow measurements were performed, and all included in-situ conductivity measurements. The in-situ conductivity measurements show a mean value of 0.92
A

CORE 3

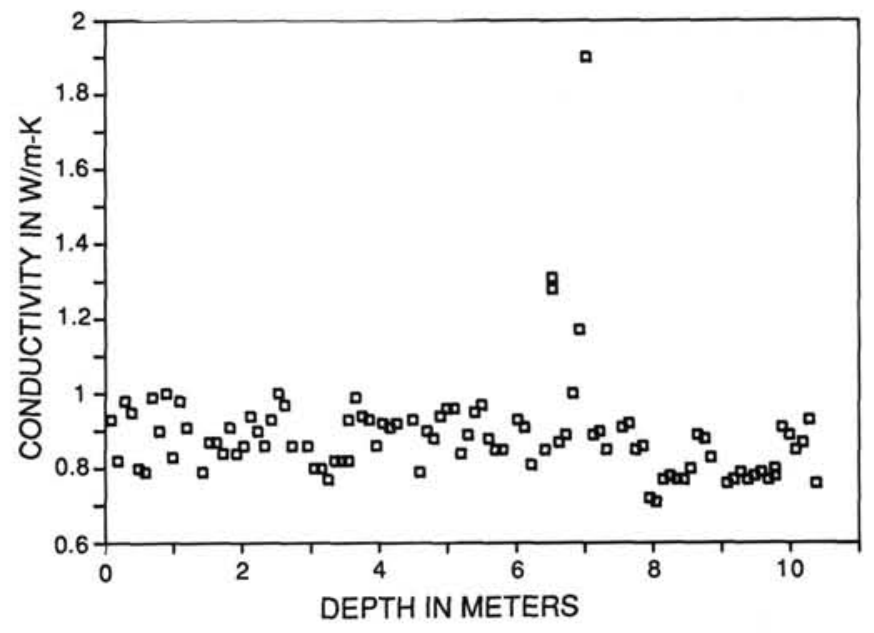

B

CORE 4

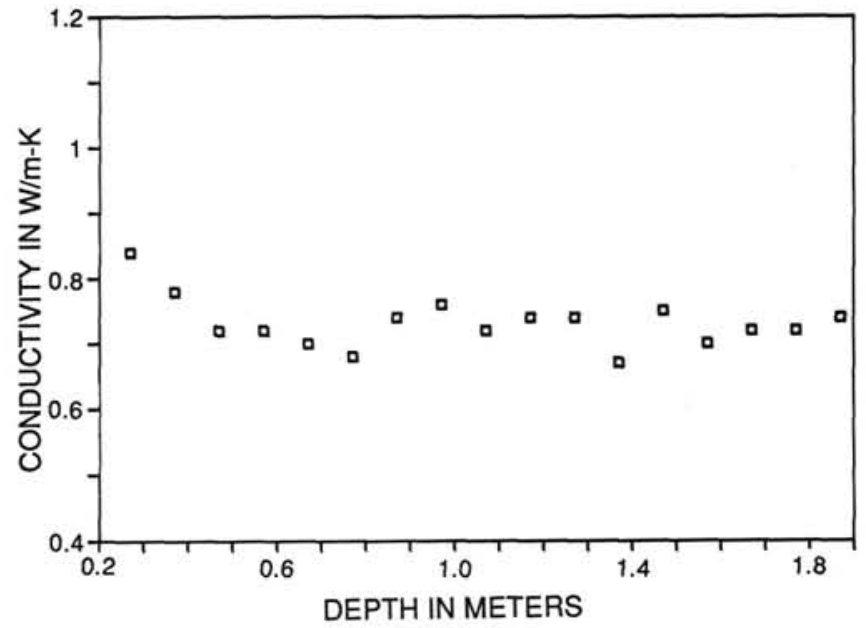

Figure 13. Measured thermal-conductivity values from the sediment cores taken near A. Site 647 and B. Site 646.

$\pm 0.02 \mathrm{~W} / \mathrm{mK}$, which is significantly greater than the needleprobe measurements $(0.73 \pm 0.04 \mathrm{~W} / \mathrm{mK})$ performed using a gravity core (Fig. 13B ) taken nearby. In our calculations of the heat-flow values we used the in-situ conductivity values, as we consider the needle probe values to be too low for this region. We got a heat-flow value of $80.2 \pm 3 \mathrm{~mW} / \mathrm{m}^{2}$ for this site. Considering that the age of the crust where heat flow was measured is about $56 \mathrm{Ma}$, the standard heat flow vs. age curves give expected heat-flow values of $63 \mathrm{~mW} / \mathrm{m}^{2}$. This is similar to what was obtained at Site 647 . Thus, we find that the measured values are higher than the normal values expected for the age of the crust at both sites.

\section{Magnetic and Gravity Anomalies}

Figure 18 shows the magnetic anomalies plotted along track lines in the survey area. Anomaly 24 lies near the site and follows a northwest/southeast direction in this region. Anomaly 23 lies to the west of it and follows the same trend. Srivastava (1978) postulated an older group of anomalies east of anomaly 24. This is clearly seen in a regional compilation of magnetic anomalies in this region (Fig. 19). This implies a drastic change in direction of movement soon after anomaly 25 time, in such a way that it completely dislocated the old anomalies and created 


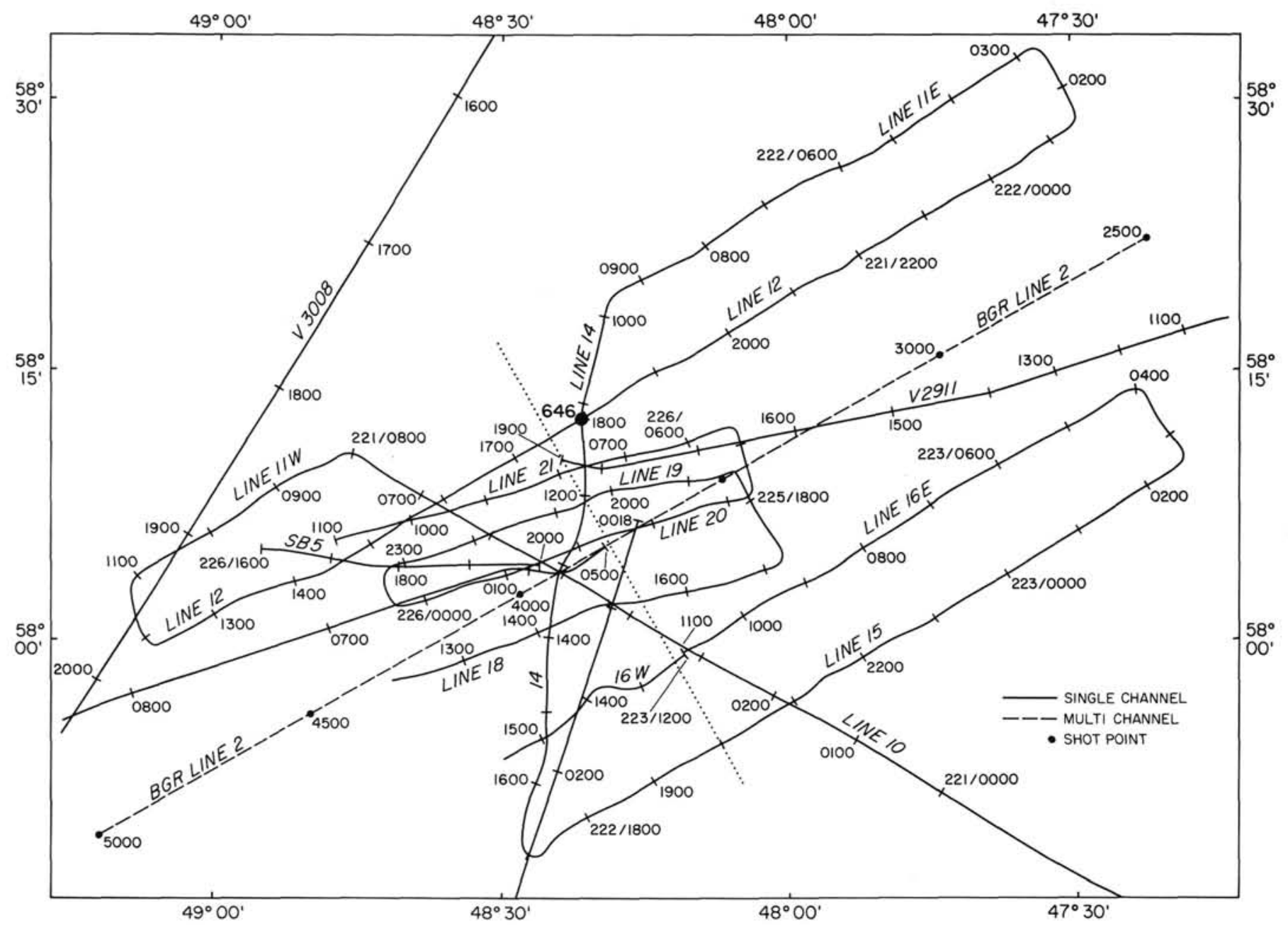

Figure 14. Map showing the location of ship track lines, with day and time, near Site 646 along which gravity, magnetic, bathymetry, and seismic data were collected during a detailed survey. The dotted line marks the position along which seismic profiles are stacked in Figure 15.

new ones at large angles to the old anomalies. This can also be seen in the basement topography, where we find presence of large relief in the basement immediately east of anomaly 24 . If we align the seismic profiles along this basement high (Fig. 20), we find that it marks a boundary differentiating smooth from rough basement. The rough basement lies in the region of younger crust, where spreading was oblique relative to the axis of spreading, thus creating smaller dislocations in the basement during its formation (Roots and Srivastava, 1984). The line, separating the smooth from rough basement, follows the anomaly 24 trend (Fig. 19). This is somewhat similar to that observed at Site 647 (Fig. 6).

Detailed gravity measurements were also conducted along the same track lines as those of the magnetic measurements. A regional map compiled from these and other measurements in the surrounding area is shown in Figure 21. This map shows a large positive anomaly immediately east of the site. This is perhaps caused by the basement topography in this area, as seen in Figure 20 .

\section{Site 645}

Figure 22 shows the ship's track line along which shallowpenetration, high-resolution seismic and bathymetric measurements were coducted on a separate cruise (HU-85-27) in the vicinity of Site 645 . As mentioned earlier, the prime reason for this survey was to obtain detailed information about the top
$100 \mathrm{~m}$ of sediments in this region. Figure 23 shows one of the seismic records across Site 645 . The upper $100 \mathrm{~m}$ of seafloor sediments are characterized by many reflectors that are parallel or subparallel to the general morphology of the present sea bed. The data indicate the presence of intervals of acoustically stratified and unstratified sediments (Fig. 23). The latter are interpreted to represent debris flow sediments. Here, these often occur as lenses and as more laterally extensive deposits, up to $30 \mathrm{~m}$ or more in thickness, interbedded with the acoustically stratified sediments. However, in places these sediments interfinger with the acoustically stratified ones, and there is a lateral transition from one to the other over a short distance (Fig. 24). Such instances may, however, be more apparent than real and may represent disruption or loading of the original sediments in the debris-flow area. The acoustically unstratified sediments in general are thicker and more prevalent on and adjacent to the lower part of the Baffin Island continental slope to the west of Site 645. The debris-flow sequences in the Site 645 area may not continue to great depths, at least on the basis of these and other seismic data collected in this region, but are mainly confined to the top $0.12 \mathrm{~s}$ of the record (approximately $90 \mathrm{~m}$ at velocity of sound in water). Other records taken in this region are included in the Appendix.

In addition to the shallow- and high-resolution seismic data, benthos piston cores were also collected near the site during the cruise, and their positions are listed in Table 2 . These cores have 

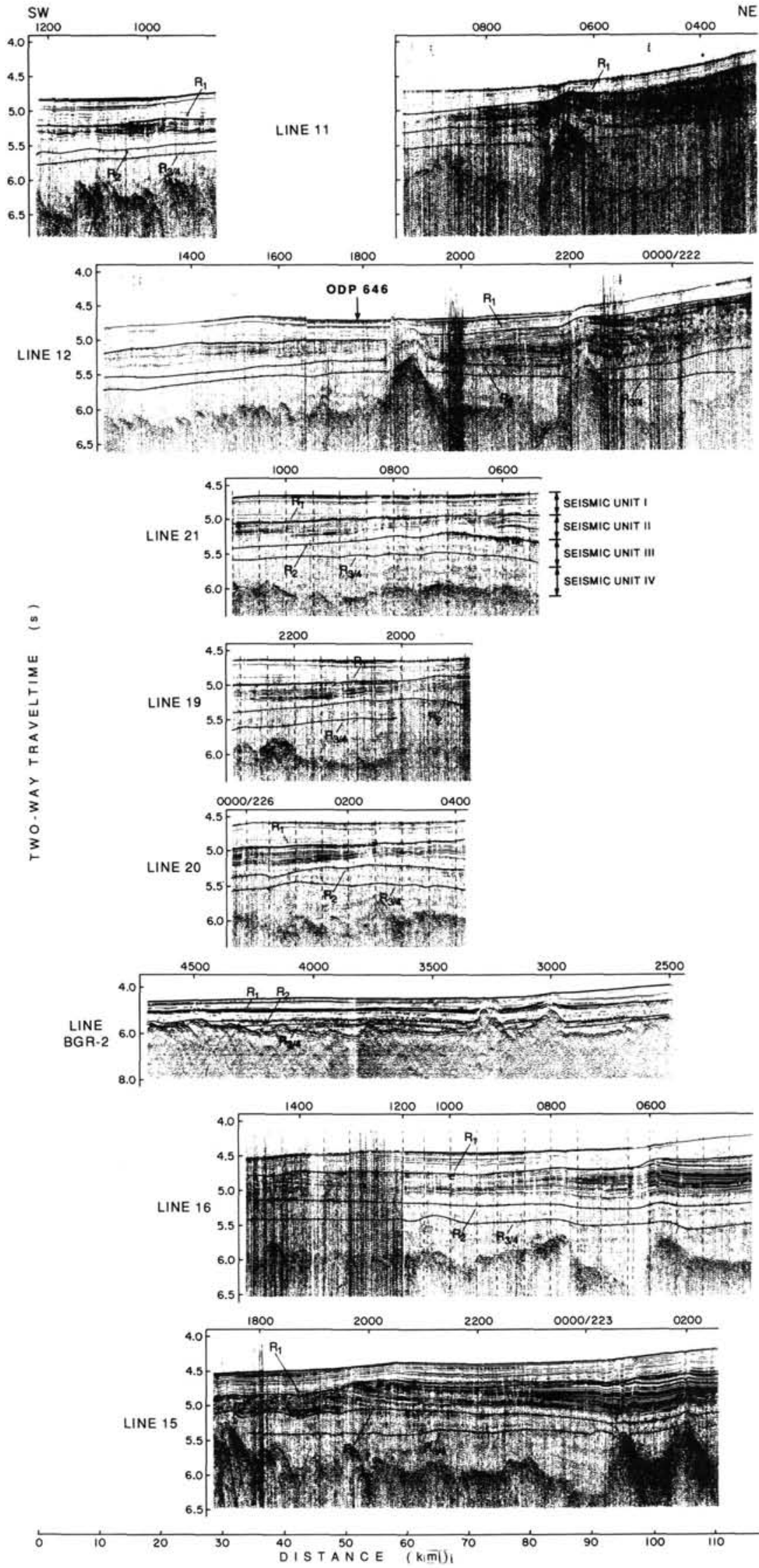

Figure 15. Stacked seimic profiles near Site 646 . The profiles have been stacked along a line shown in Figure 14. 

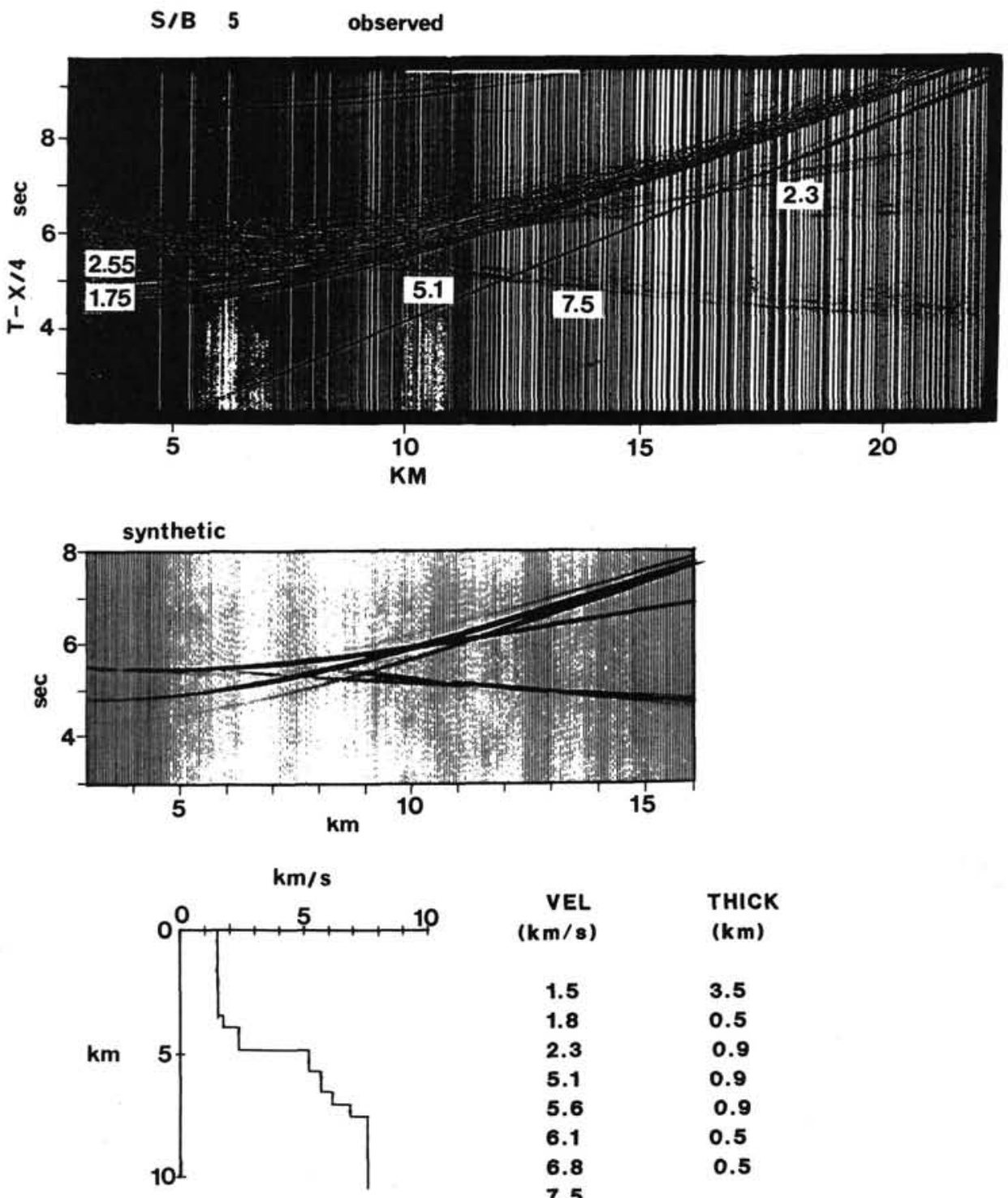

$\begin{array}{rc}\begin{array}{r}\text { VEL } \\ (\mathrm{km} / \mathrm{s})\end{array} & \begin{array}{c}\text { THIC } \\ (\mathrm{km})\end{array} \\ & \\ 1.5 & 3.5 \\ 1.8 & 0.5 \\ 2.3 & 0.9 \\ 5.1 & 0.9 \\ 5.6 & 0.9 \\ 6.1 & 0.5 \\ 6.8 & 0.5 \\ 7.5 & \end{array}$

Figure 16. Recordings from a sonobuoy near Site 646 and the synthetic seismogram generated from the interpreted velocity distribution.

been described in detail by Scott et al. (in this volume) and Hillaire-Marcel et al. (this volume), who conducted detailed analyses on the samples from these cores.

\section{SUMMARY}

When combined with existing regional data, detailed geological and geophysical data collected during a site survey cruise to the Labrador Sea helped us to delineate many seismic reflectors and some structural boundaries at the two sites. The results from the survey have shown that:

1. Even though the two drill sites are located on crusts that are of approximately the same general age, they contain sedimentary sections that exhibit very different characteristics. This is also borne out by the drilling results.

2. The sedimentary section at Site 646 contains two prominent reflectors that differ significantly in their characteristics from those present at Site 647 . The reflectors at each of these sites may be continuous within the region surveyed and can be extended to the neighboring regions using the network of seismic lines that exist at each site, but not through to Baffin Bay.

3. The change in the character of the basement seen at each site can be related to the changes in the direction of spreading there.

4. Heat flows measured at the two sites show higher than expected values for these regions. In fact, these values should be higher still once the effect of higher sedimentation rates during the Quaternary are included. If further modeling proves that this correction is valid, the heat flow for Site 646 may be up to $20 \%$ to $25 \%$ higher than normal. Similar increases in heat-flow values have been observed elsewhere in the Atlantic Ocean to be associated with mid-plate hot spots (e.g., Courtney and White, 1986). Thus, an enhanced value at Site 646 may possibly be a remnent of a thermal plume that Hyndman (1973) and others scientists suggested as passing through the eastern section of the Labrador Sea during its opening. Possibilities of this are further discussed by Srivastava and Arthur (this volume). 


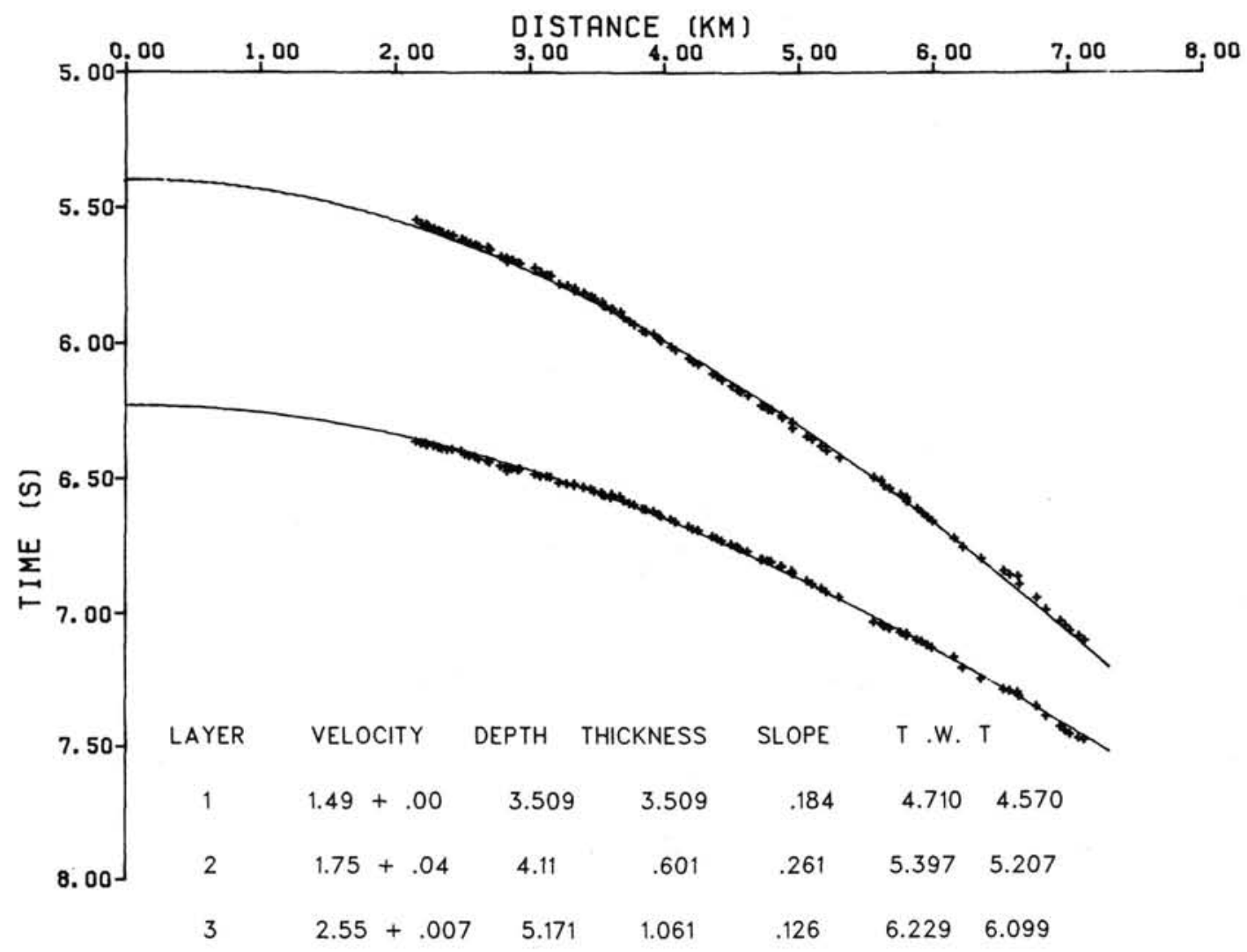

Figure 17. Plot of the wide-angle reflections from the sonobuoy near Site 646 together with the velocity distribution, as obtained from the best fit of the data.

5. High-resolution seismic measurements in the vicinity of Site 645 show possibility of debris flow within the top $90 \mathrm{~m}$ of the section.

\section{ACKNOWLEDGMENTS}

We thank the master, officers, and crew of the Hudson for their diligence in sailing straight courses, collecting cores, and performing overthe-side work in winds in excess of 20 knots. We also acknowledge the valuable support from the staff of the Atlantic Geoscience Centre for collecting data during these cruises. The drafting and illustration section of the Bedford Institute of Oceanography prepared our drawings. We thank John Woodside for his comments and discussion. This is Geological Survey of Canada Contribution No. 43988.

\section{REFERENCES}

Chough, S. K., Mosher, D. C., and Srivastava, S. P., 1985. Ocean Drilling Program (ODP) site survey (Hudson 84-30) in the Labrador Sea: $3.5 \mathrm{kHz}$ profiles. Geol. Surv. Can. Pap., 85-1B:33-41.

Courtney, R. C, and White, R. S., 1986. Anomalous heat flow and geoid across the Cape Verde Rise: evidence for dynamic support from a thermal plume in the mantle. Geophys. J. Roy. Astron. Soc., $87: 815-867$.

Damuth, J. E., 1980. Use of high-frequency (3.5-12 kHz) echograms in study of near-bottom sedimentation processes in the deep sea: $\mathrm{A}$ review. Mar. Geol., 38:51-75.

Hutchison, I., and Owen. T., 1988. A microprocessor heat flow probe. In Wright, J. A, and Louden, K. E. (Eds.), Handbook of Marine Heat Flow: Boca Ratan, FL (CRC Press).

Hyndman, R. D., Roger, G. C., Bone, M. N., Lister, C.R.B., Wade, U. S., Barret, D. L., Davis, E. E., Lewis, T., Lynch, S., and Seeman, D., 1978. Geophysical measurements in the region of the Explorer Ridge off western Canada. Can. J. Earth Sci., 15:1508-1525.
Hyndman, R. D., 1973. Evolution of the Labrador Sea. Can. J. Earth Sci., 10:637-644.

Miller, K. G., and Tucholke, B. E., 1983. Development of Cenozoic abyssal circulation south of Greenland-Scotland Ridge. In Bott, M. P., Saxov, S., Talwani, M., and Thiede, J. (Eds.), Structure and Development of the Greenland-Scotland Ridge: New York (Plenum Press), 549-589.

Roots, W. D., and Srivastava, S. P., 1984. Origin of the magnetic quiet zones in the Labrador and Greenland seas. Mar. Geophys. Res., 6:395-408.

Srivastava, S. P., 1978. Evolution of the Labrador Sea and its bearing on the early evolution of the North Atlantic. Geophys. J. Roy. Astron. Soc., 52:313-357.

Srivastava, S. P., Arthur, M. A., et al., 1987. Proc. ODP, Init. Repts., 105: College Station, TX (Ocean Drilling Program).

Srivastava, S. P., Verhoef, J., and Macnab, R., 1988. Results from a detailed aeromagnetic survey across the Northeast Newfoundland margin: Part I. Spreading anomalies and the relationship between oceancontinent boundary and the magnetic anomalies. Mar. Pet. Geol., 5: 306-323.

Von Herzen, R. P., and Maxwell, A. E., 1959. Measurement of heat flow at the preliminary Mohole Site off Mexico. J. Geophys. Res., 69:741.

Wright, J. A., and Fang, C., 1988. A microprocessor-based heat flow probe with solid-state memory. In Wright, J. A., and Louden, K. E. (Eds.), Handbook of Marine Heat Flow Boca Ratan, FL (CRC Press),

Date of initial receipt: 27 June 1988

Date of acceptance: 3 January 1989 Ms 105B-168 


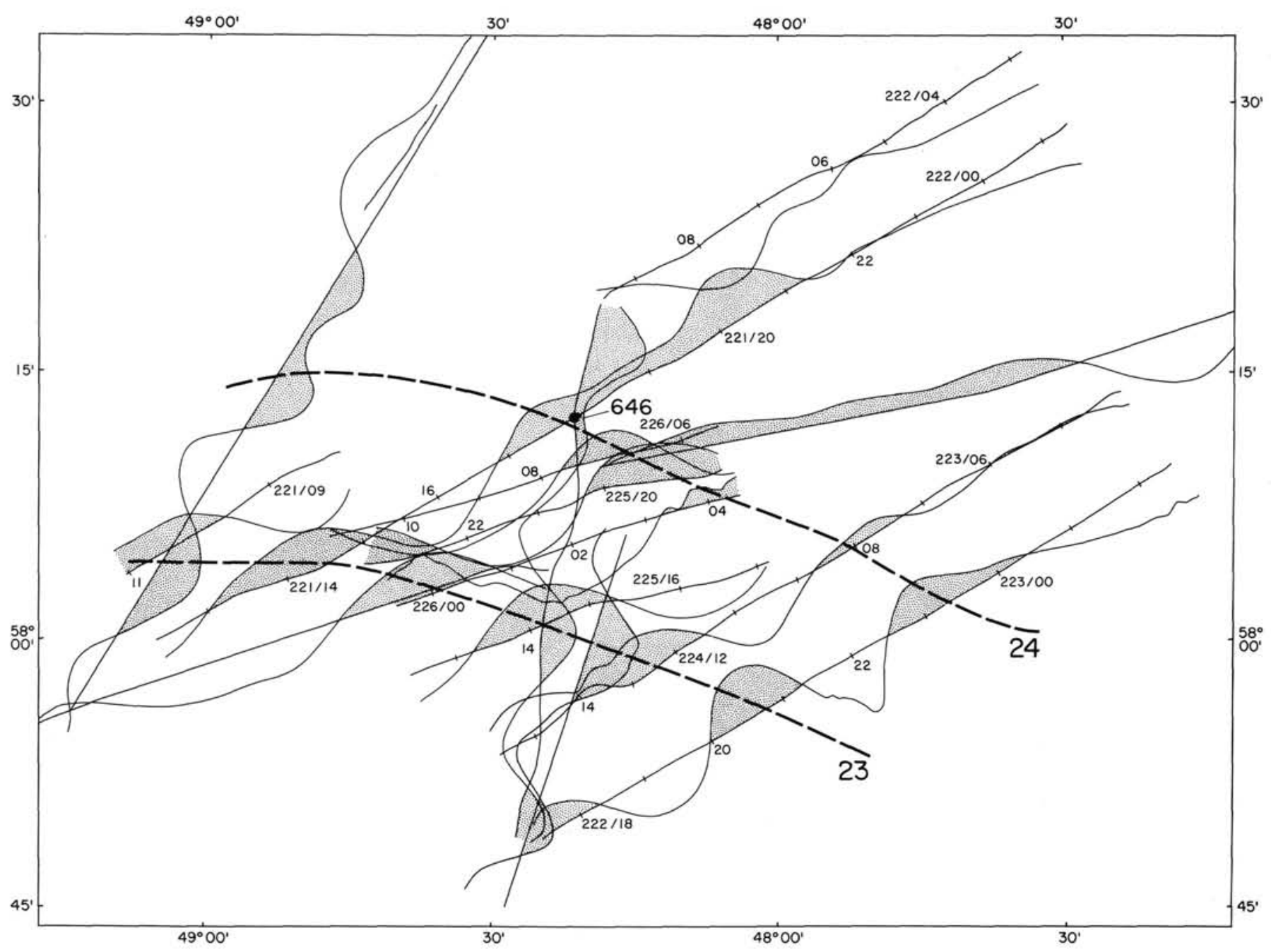

Figure 18. Correlation of magnetic anomalies between track lines near Site 646.

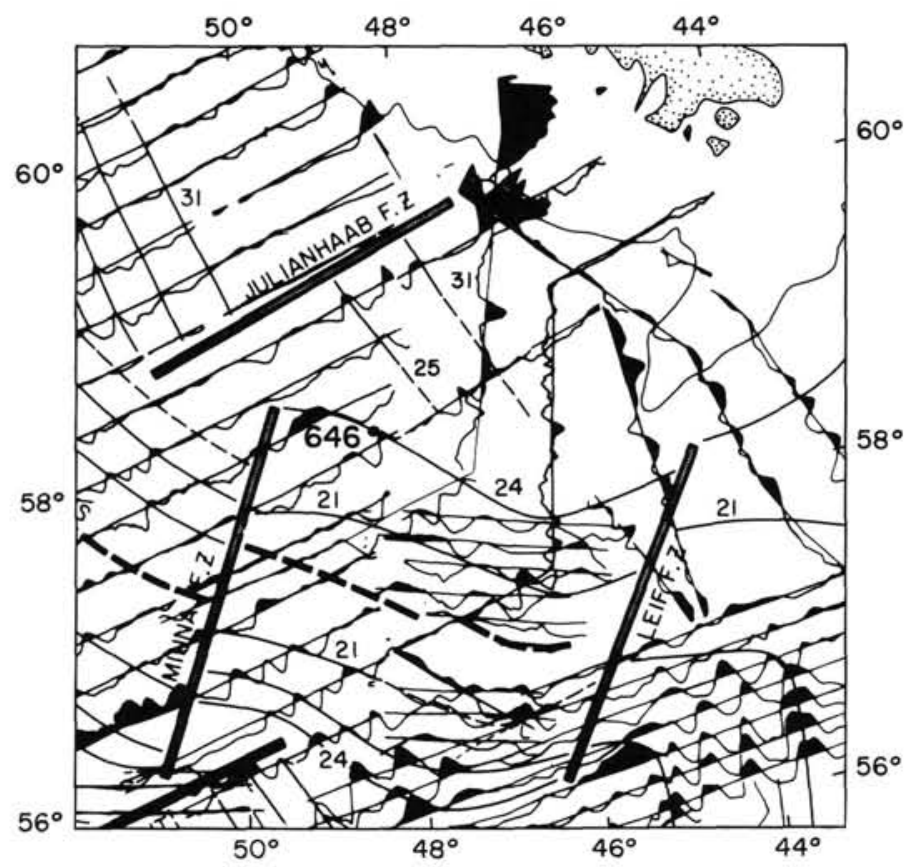

Figure 19. Magnetic anomalies in the vicinity of Site 646 . 

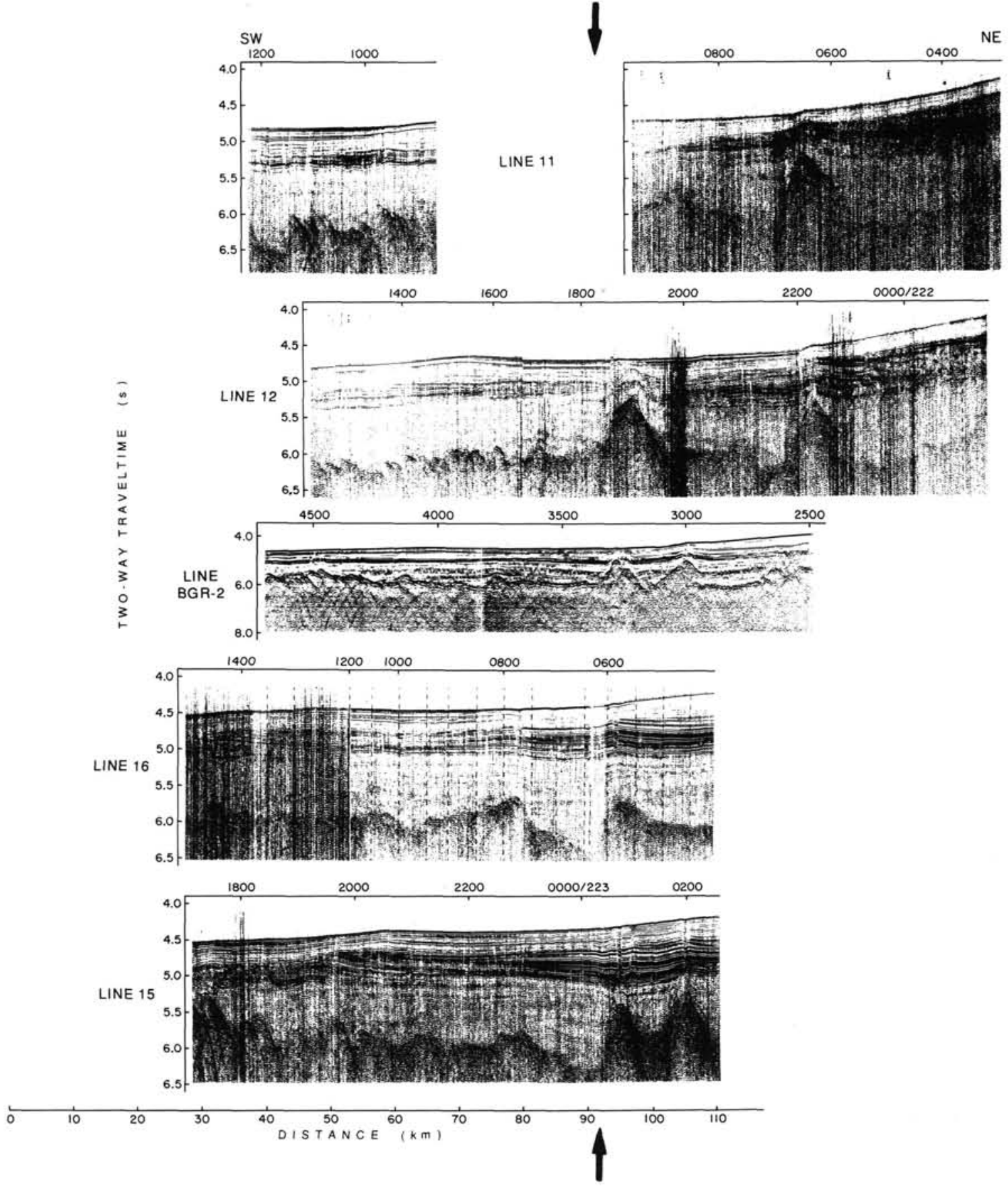

Figure 20. Seismic profiles in the vicinity of Site 646 (for location see Fig. 14) aligned along a line (shown by arrows) marking a change from smooth to rough basement topography. 


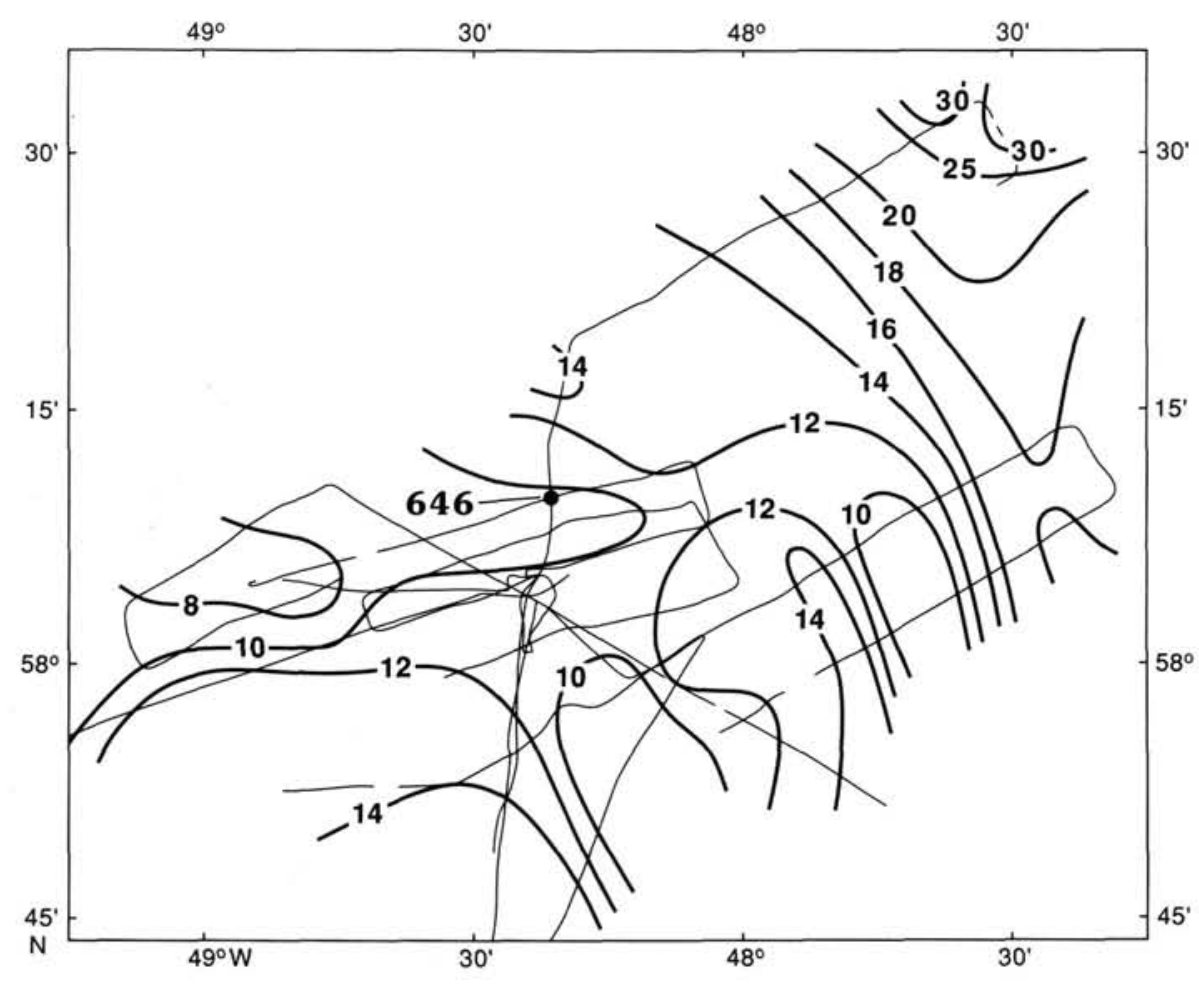

Figure 21. Free-air gravity map of Site 646 . Contour values in mgal.

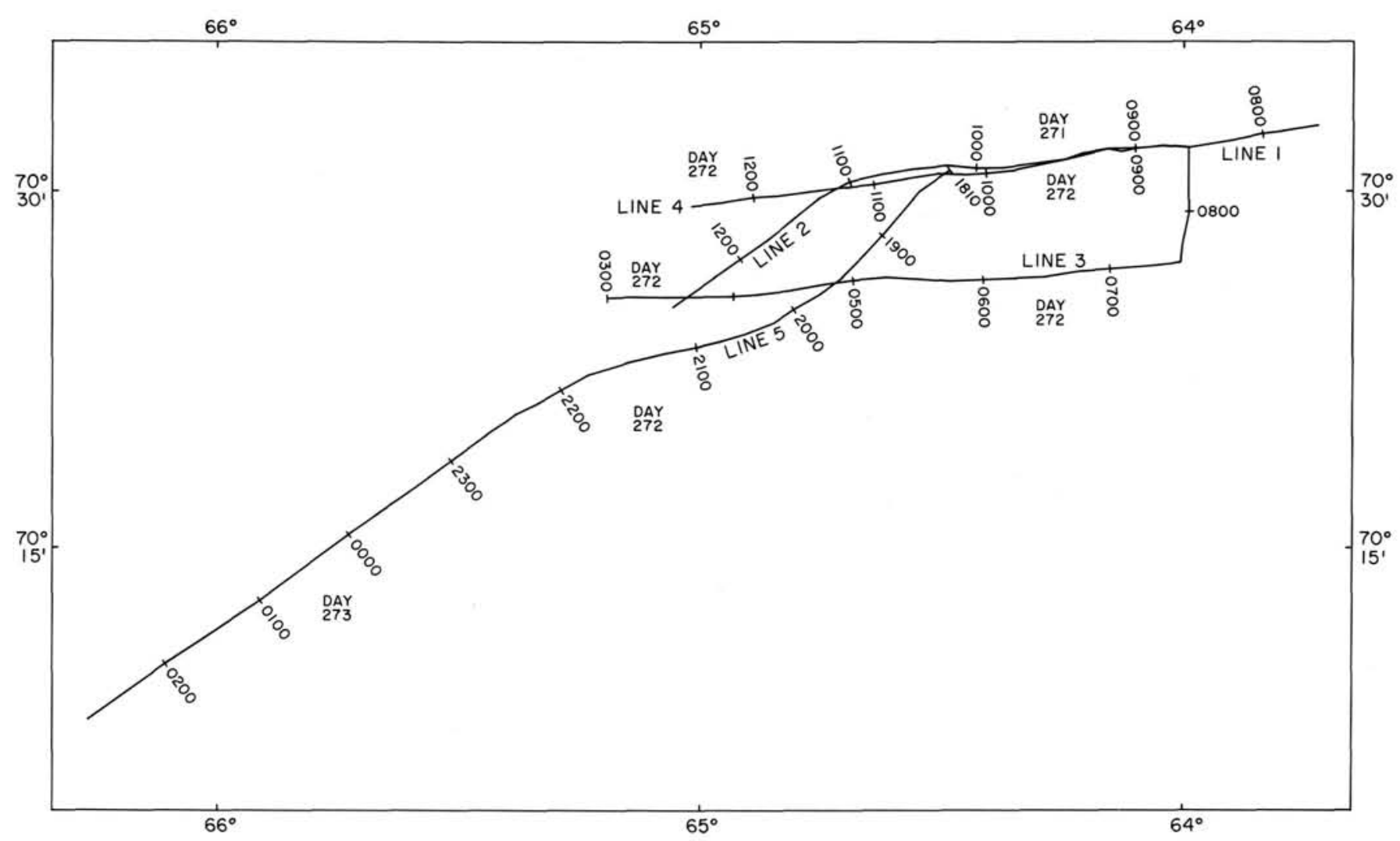

Figure 22. Ship's track lines along which high-resolution seismic data were collected in the vicinity of Site 645 during a cruise of the Hudson (HU-8527). 


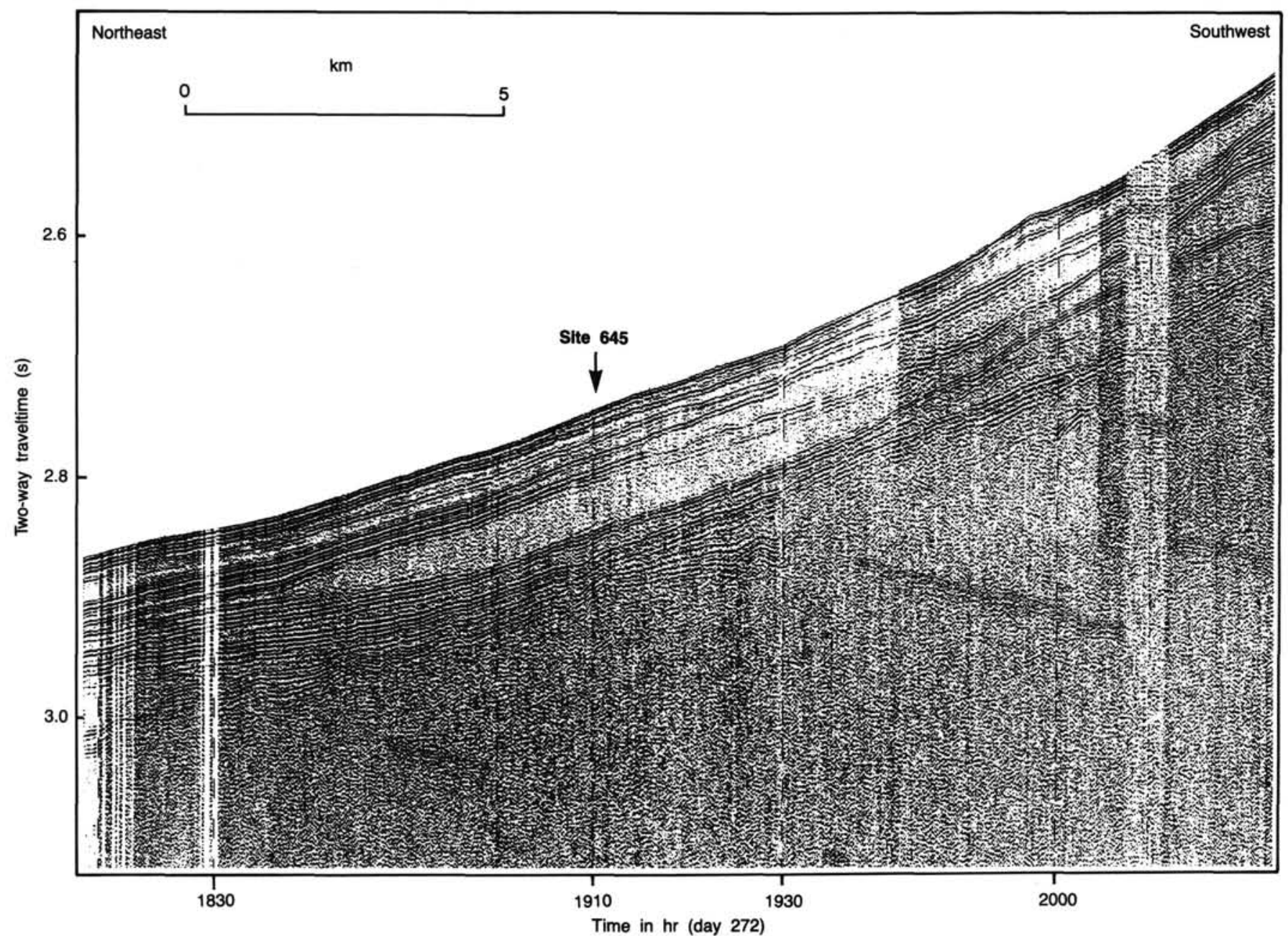

Figure 23. Single-channel, high-resolution seismic line across Site 645 . 


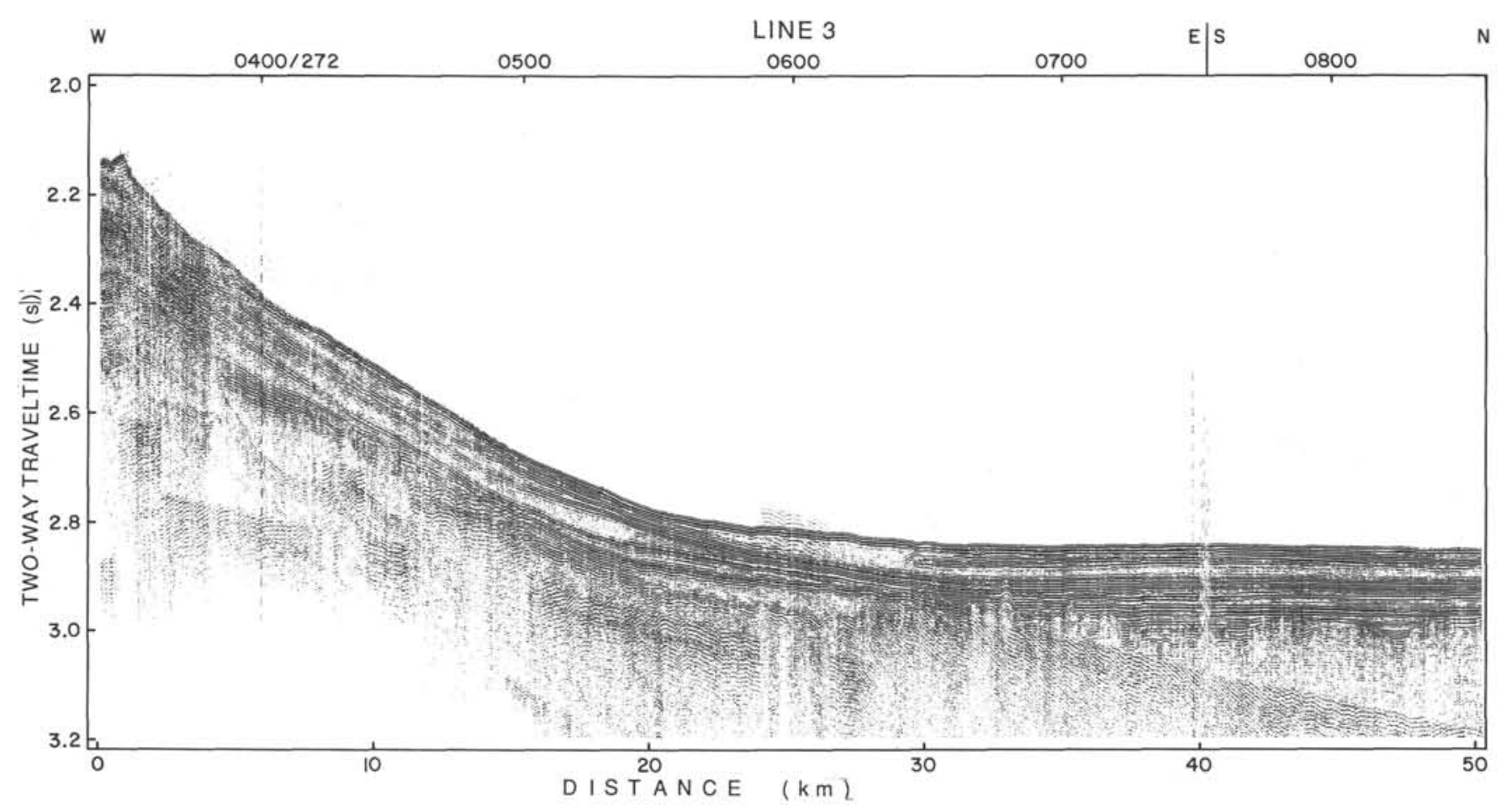

Figure 24. Single-channel, high-resolution seismic line in the vicinity of Site 645.

\section{APPENDIX}

Included here are copies of all seismic data that were collected during the two cruises, as described earlier (Figs. 25 through 48 ). These records have been annotated with necessary information. Their locations are given in Figures 3,14, and 22. The enlarged copies of these data can be obtained from the Site Survey Data Bank or from the senior author.

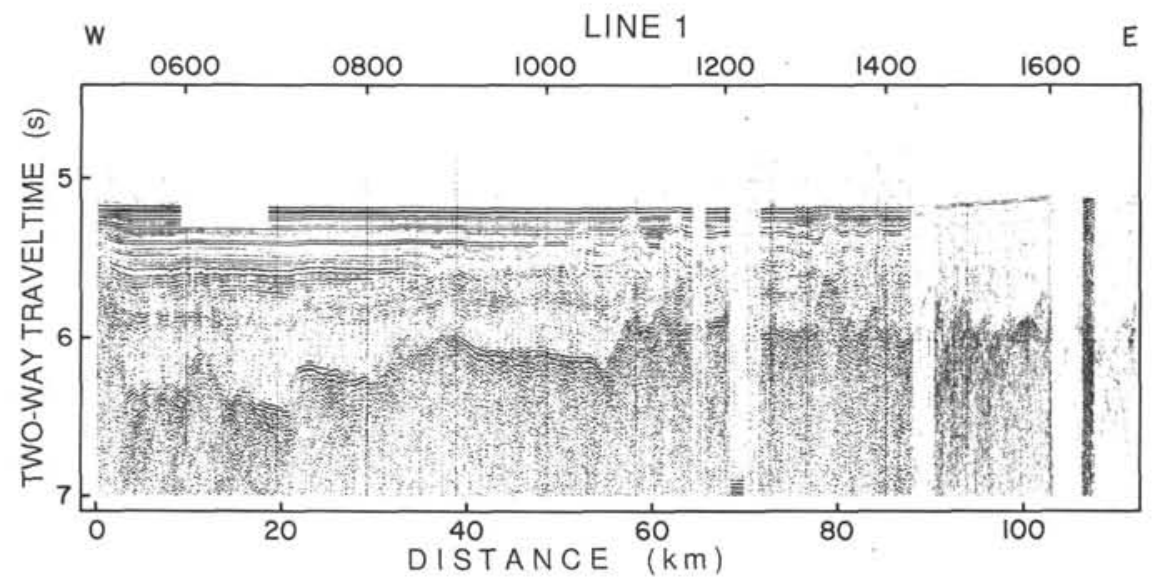

Figure 25. Single-channel seismic profile near Site 647 whose location is shown in Figure 3. 


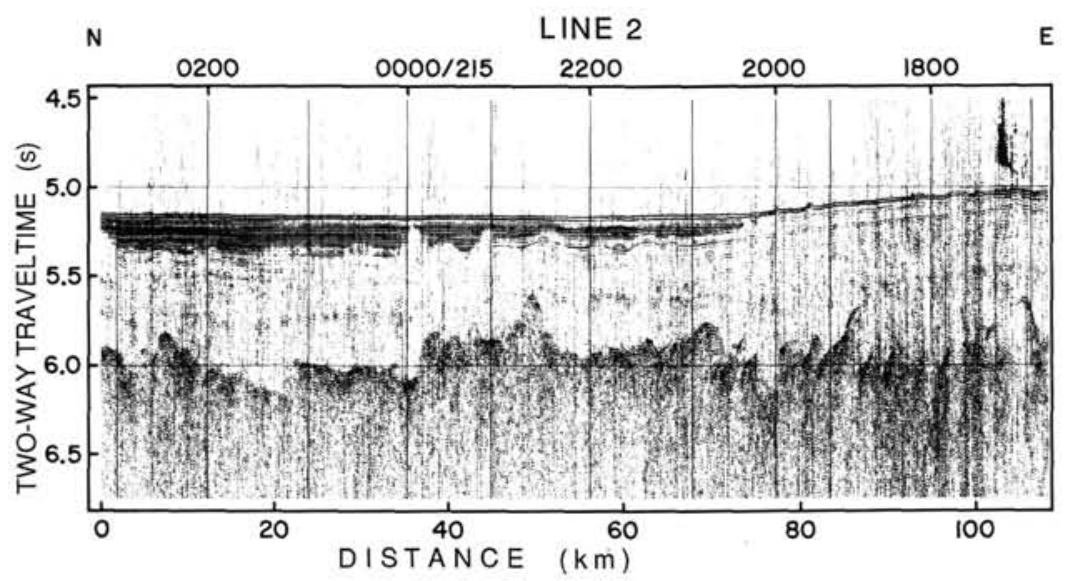

Figure 26. Single-channel seismic profile near Site 647 whose location is shown in Figure 3.

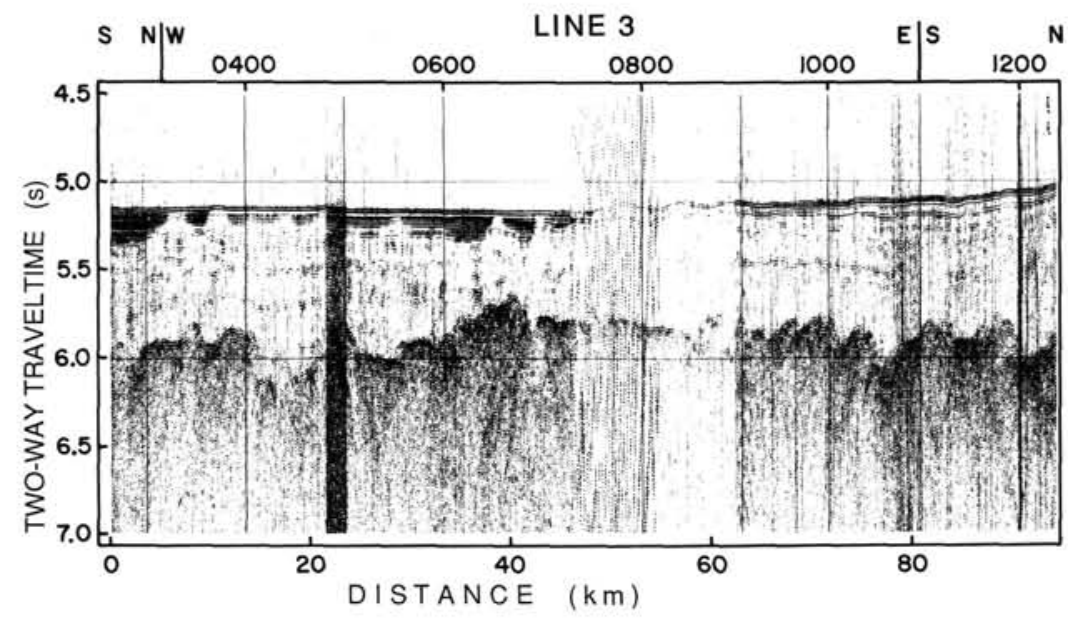

Figure 27. Single-channel seismic profile near Site 647 whose location is shown in Figure 3.

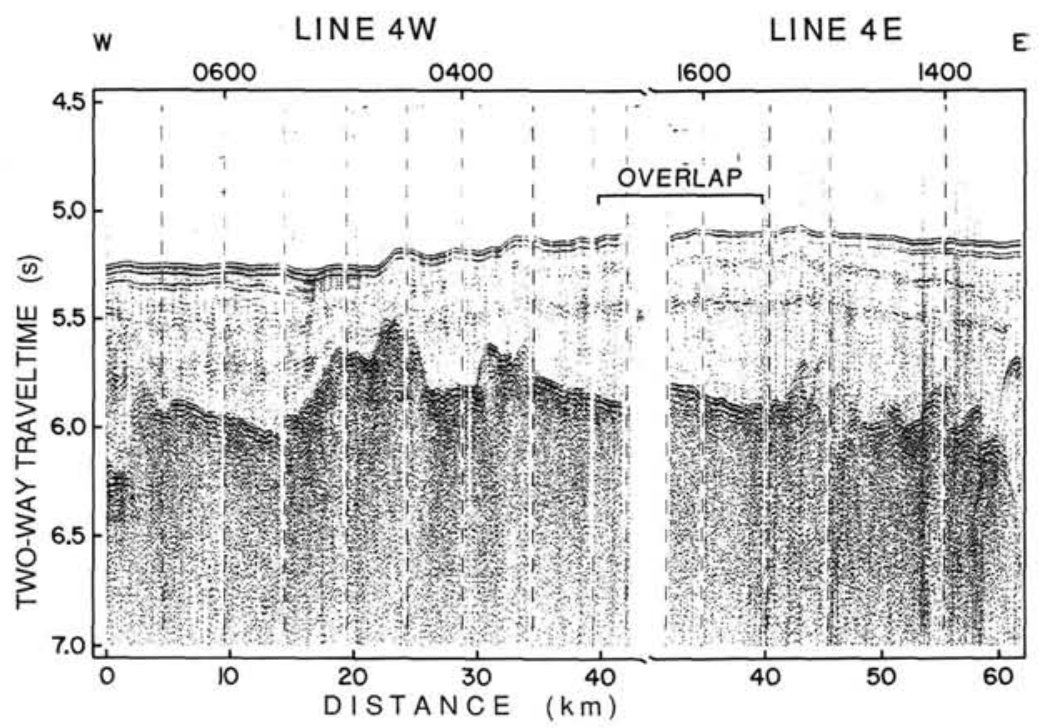

Figure 28. Single-channel seismic profile near Site 647 whose location is shown in Figure 3. 


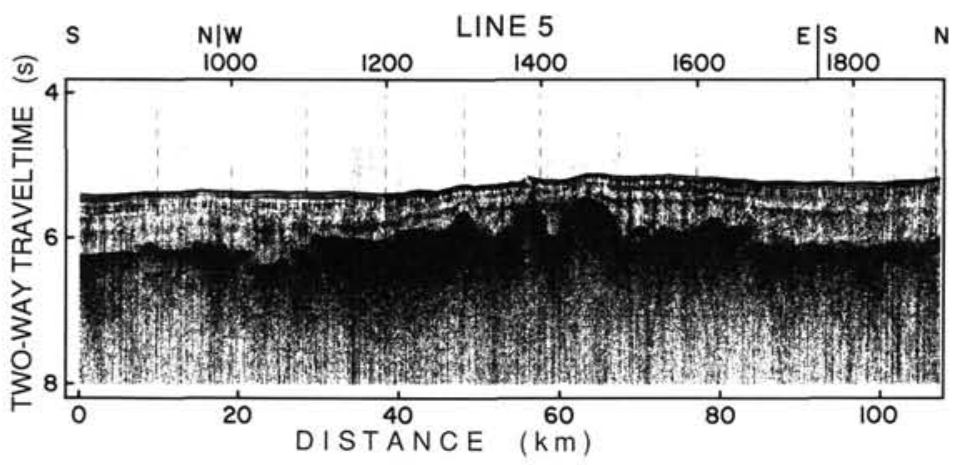

Figure 29. Single-channel seismic profile near Site 647 whose location is shown in Figure 3.

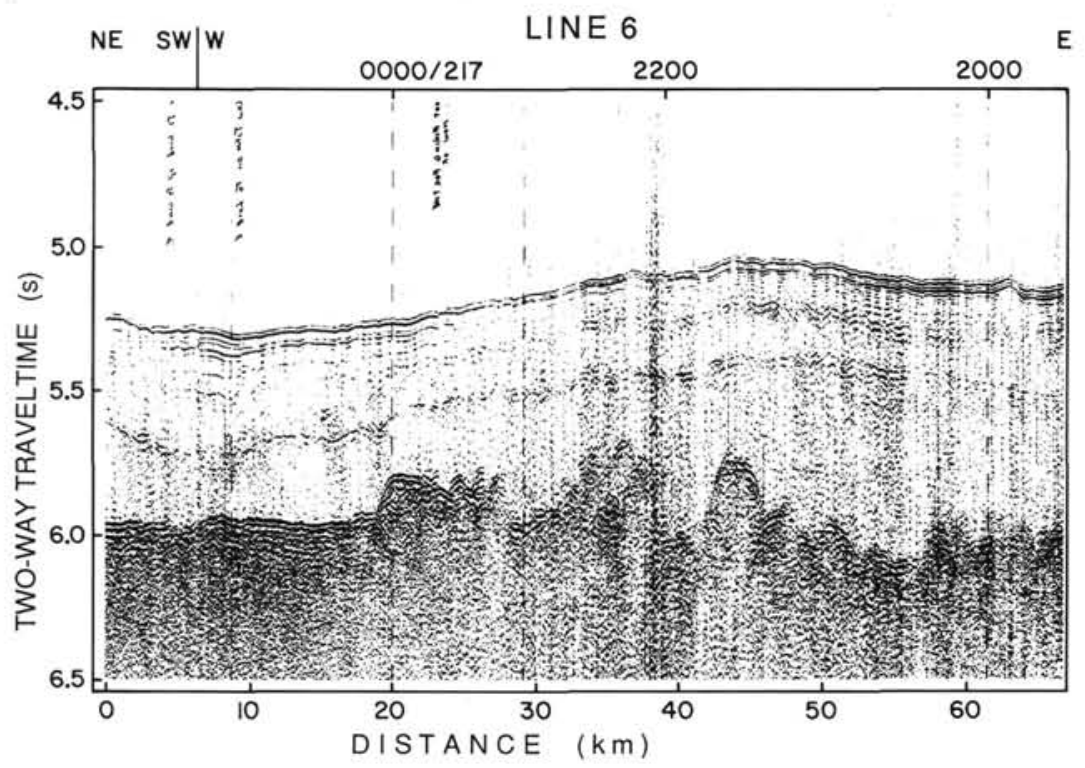

Figure 30. Single-channel seismic profile near Site 647 whose location is shown in Figure 3.

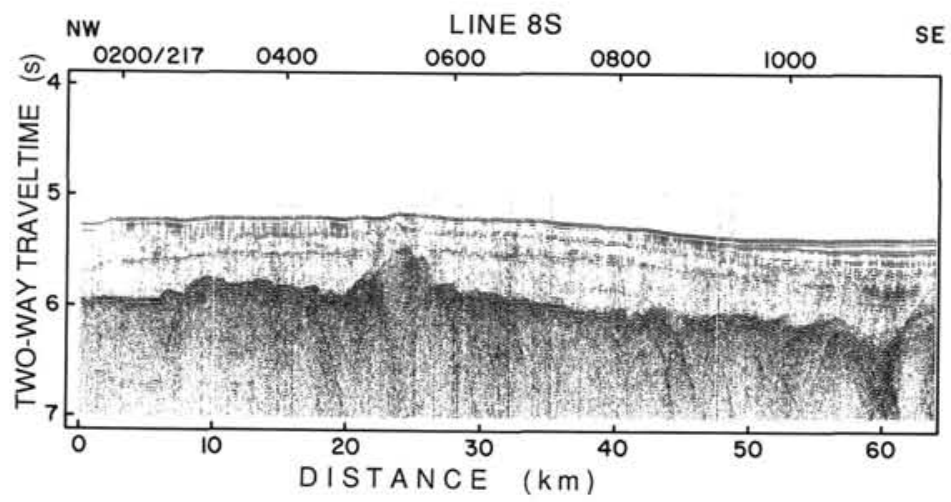

Figure 31. Single-channel seismic profile near Site 647 whose lcoation is shown in Figure 3. 


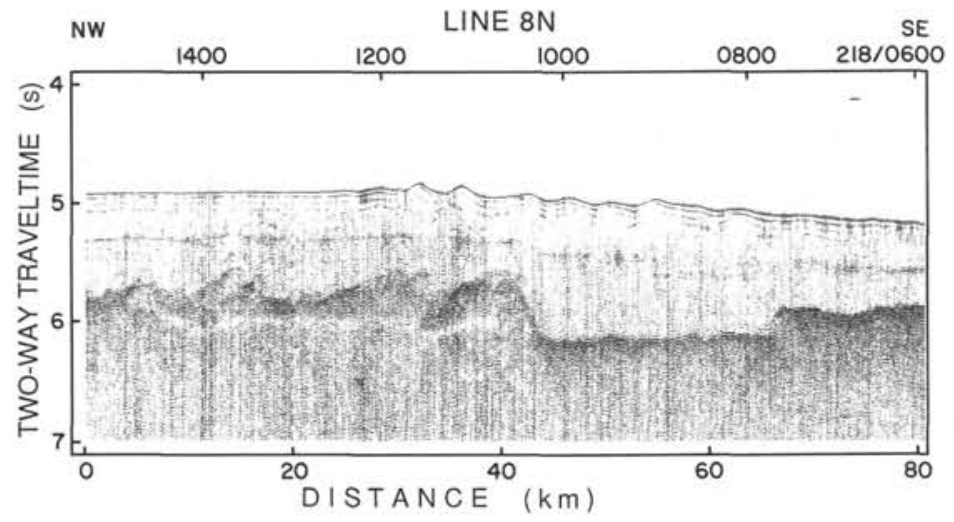

Figure 32. Single-channel seismic profile near Site 647 whose location is shown in Figure 3,

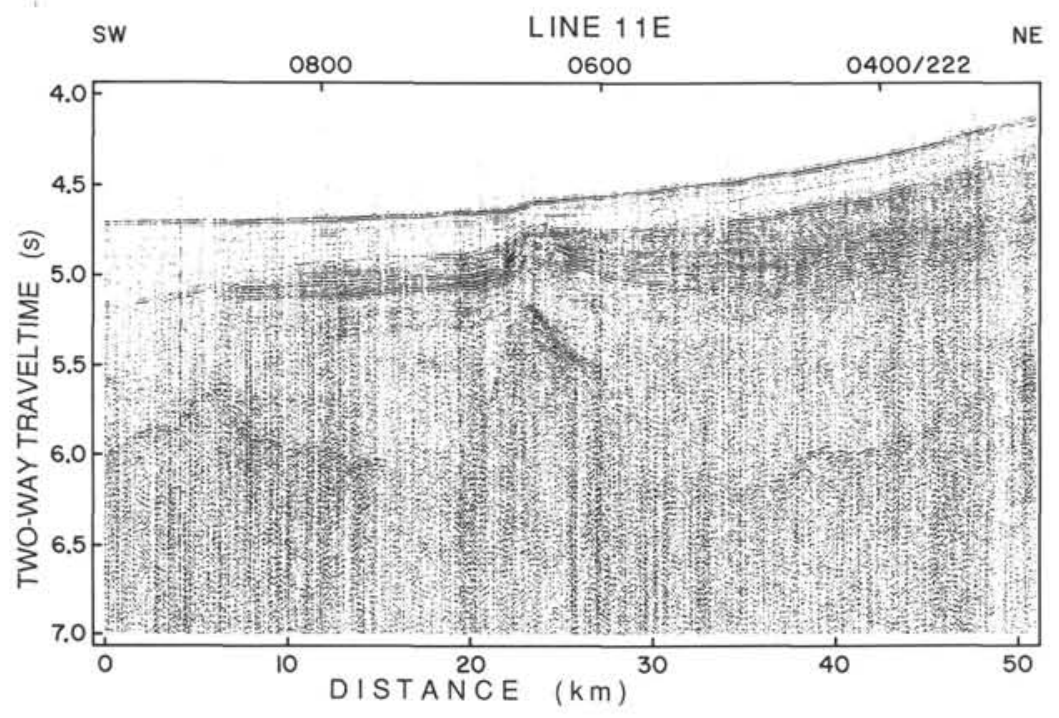

Figure 33. Single-channel seismic profile near Site 646 whose location is shown in Figure 14. 


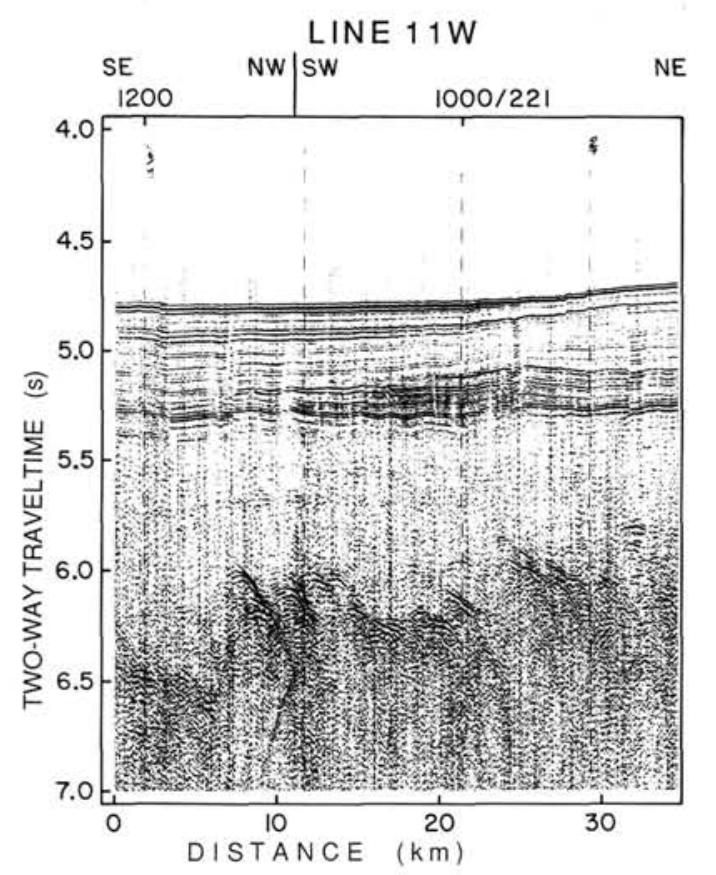

Figure 34. Single-channel seismic profile near Site 646 whose location is shown in Figure 14.

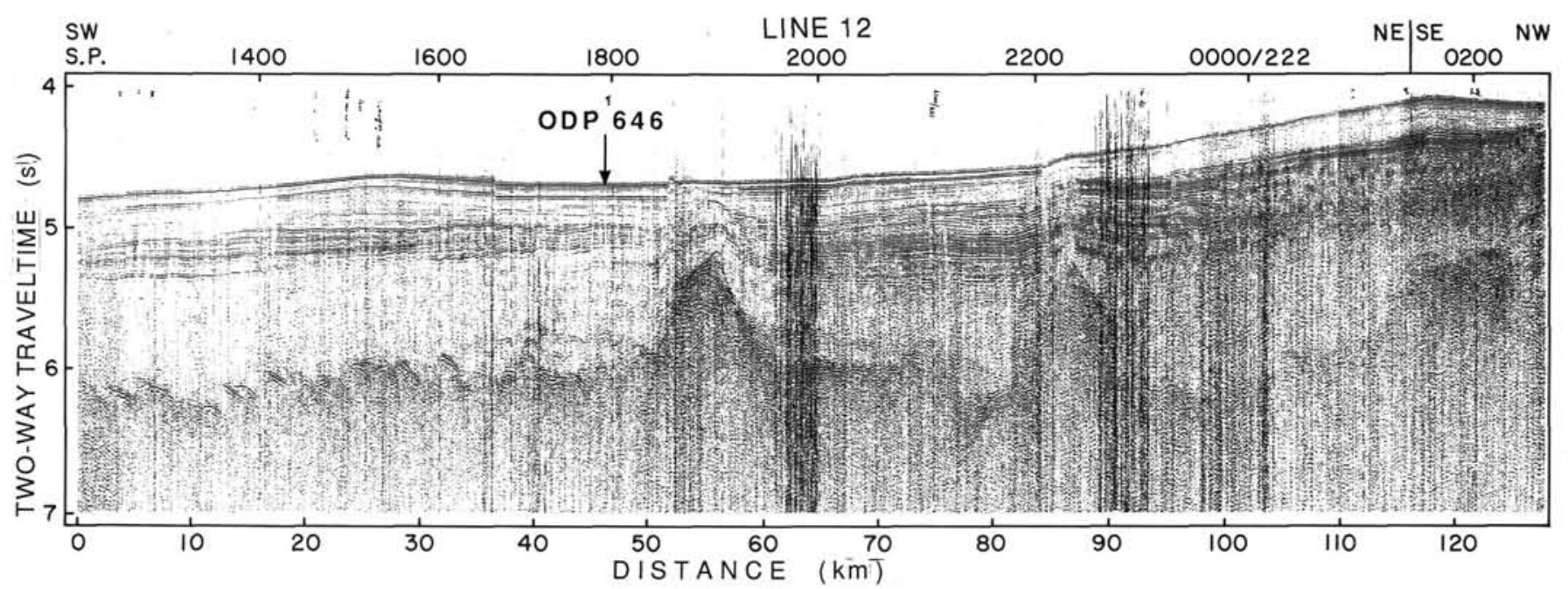

Figure 35. Single-channel seismic profile near Site 646 whose location is shown in Figure 14. 


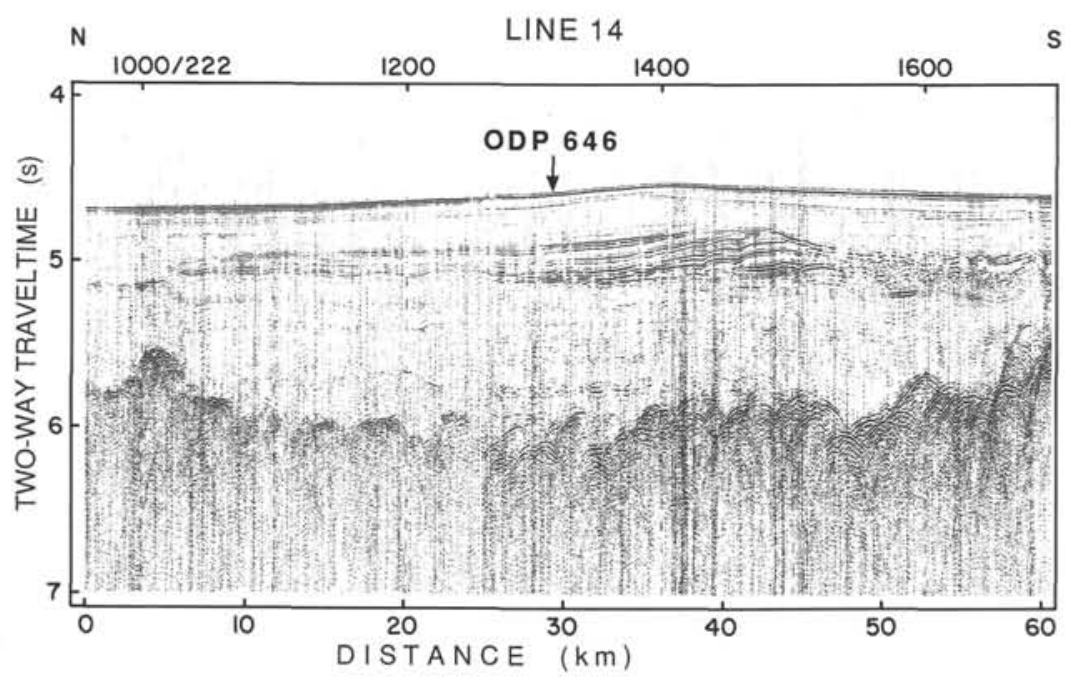

Figure 36. Single-channel seismic profile near Site 646 whose location is shown in Figure 14.

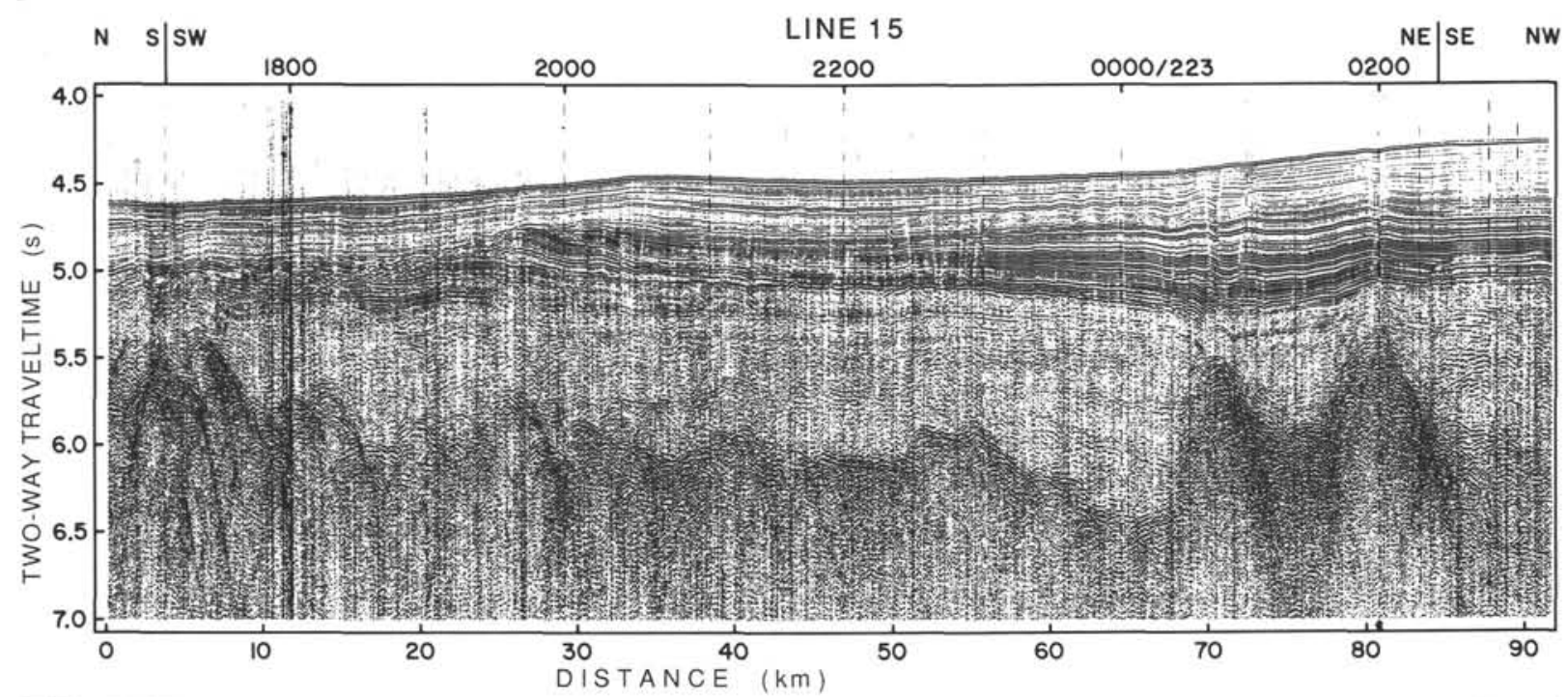

Figure 37. Single-channel seismic profile near Site 646 whose location is shown in Figure 14. 


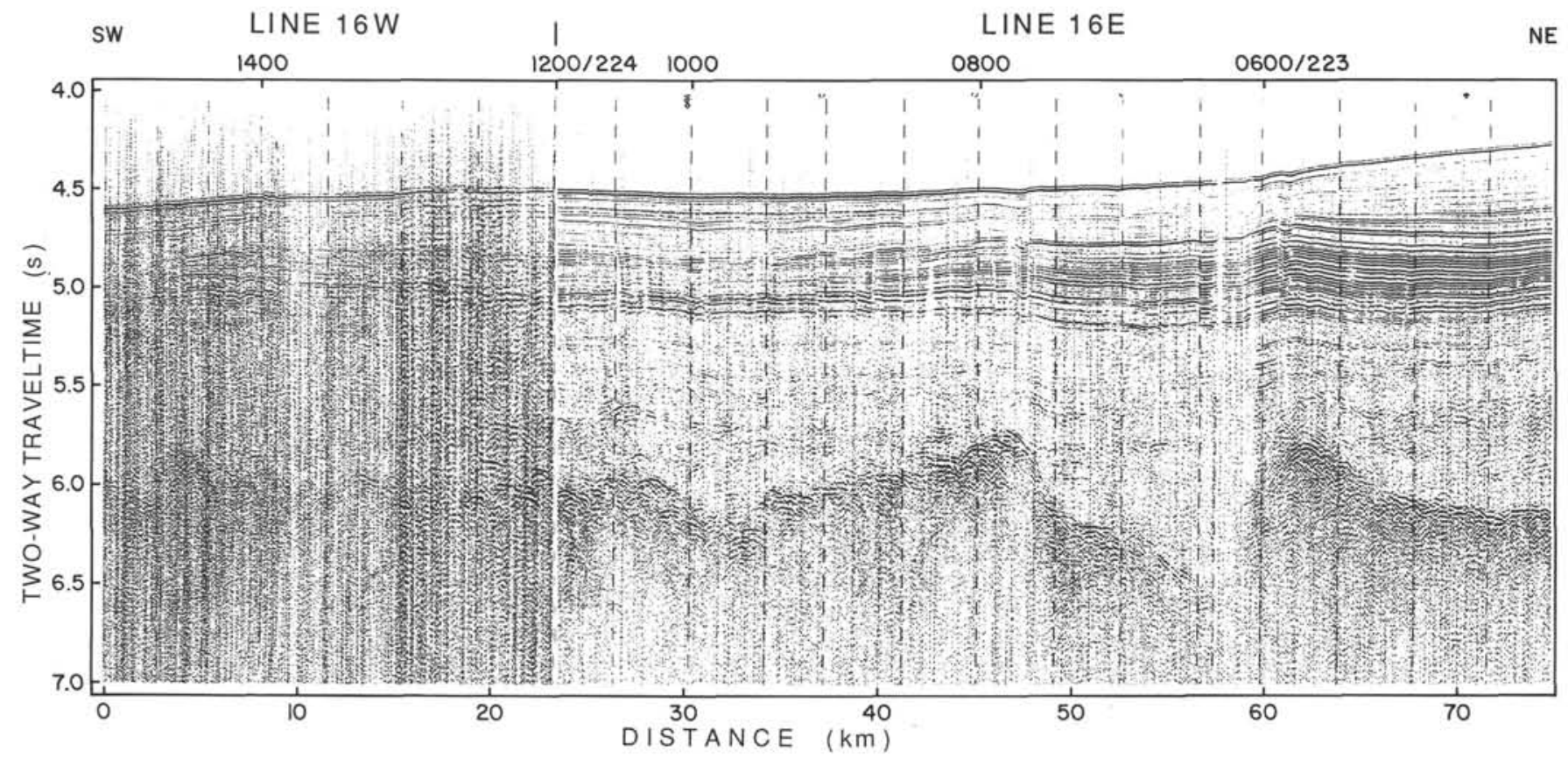

Figure 38. Single-channel seismic profile near Site 646 whose location is shown in Figure 14.

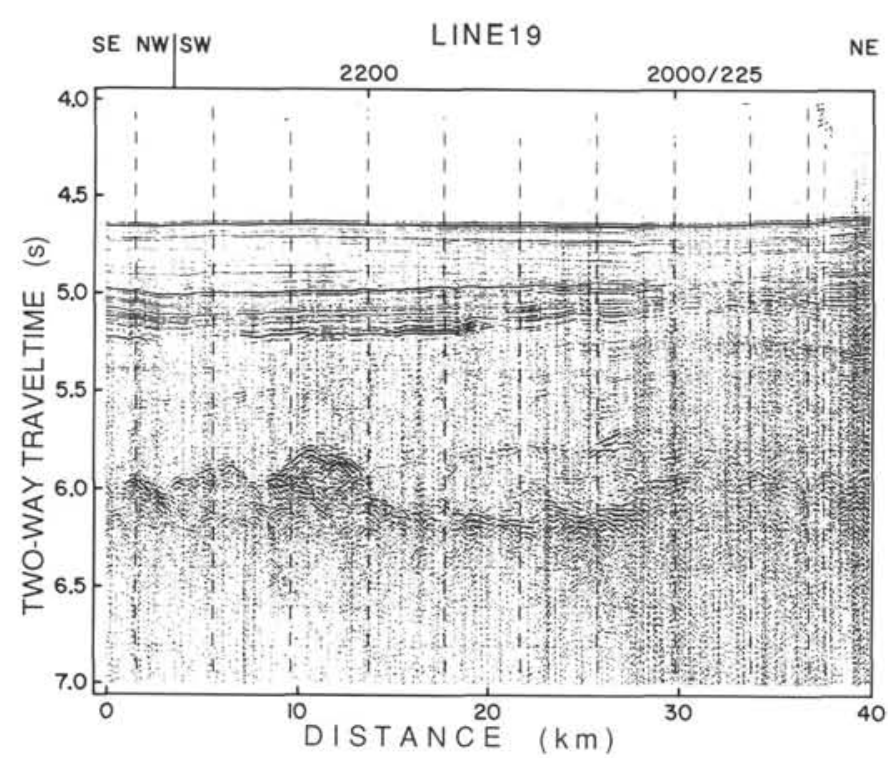

Figure 39. Single-channel seismic profile near Site 646 whose location is shown in Figure 14.

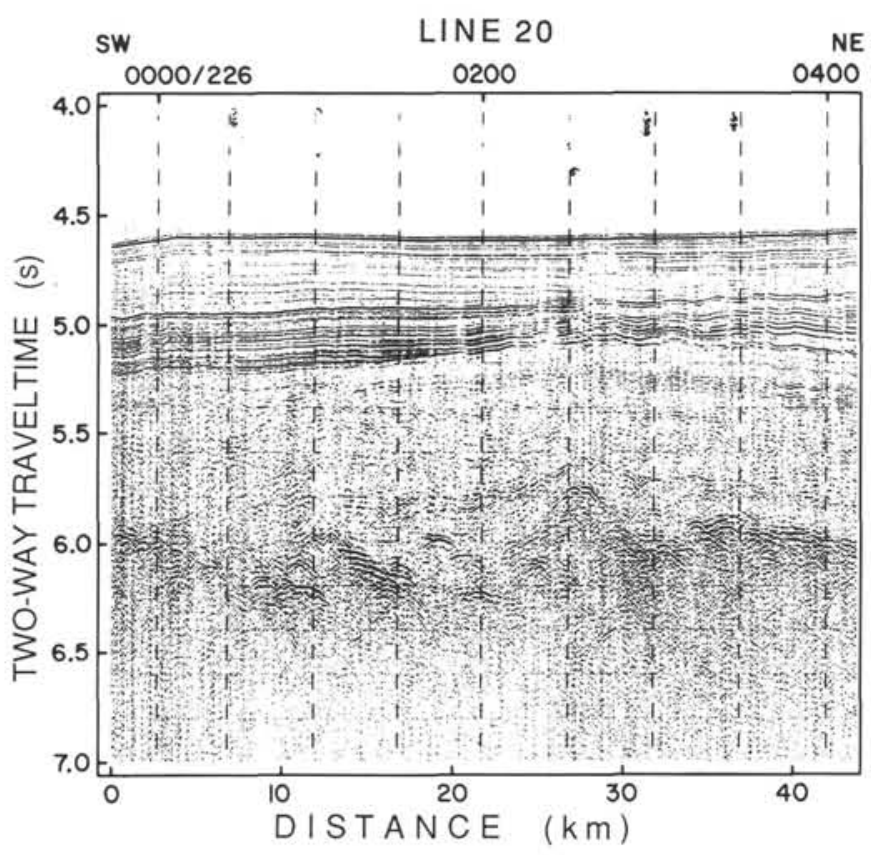

Figure 40 . Single-channel seismic profile near Site 646 whose location is shown in Figure 14. 


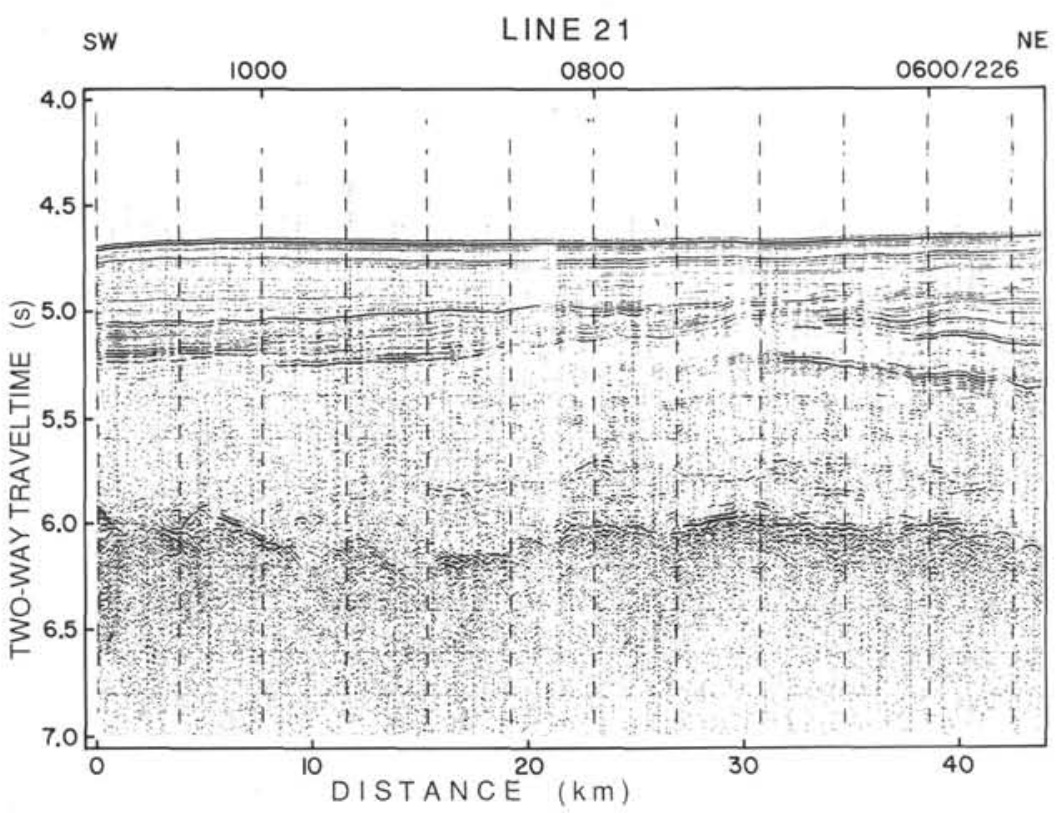

Figure 41. Single-channel seismic profile near Site 646 whose location is shown in Figure 14.

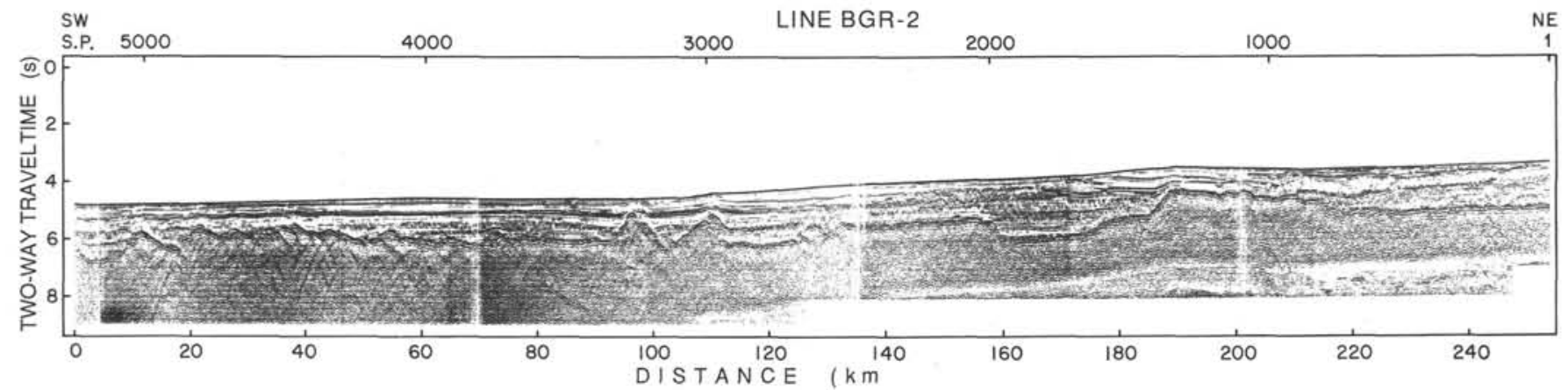

Figure 42. Multichannel profile BGR-2 near Site 646 whose location is shown in Figure 14.

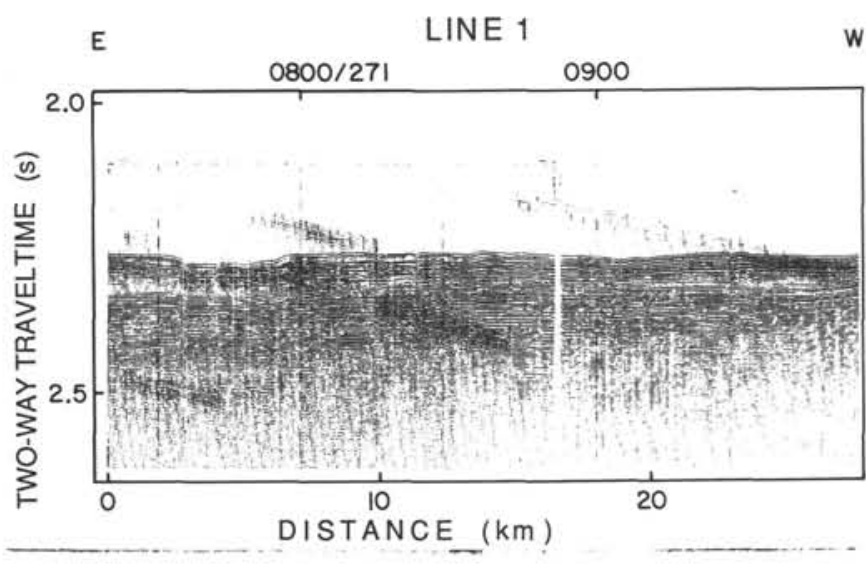

Figure 43. High-resolution seismic profile near Site 645 whose location is shown in Figure 22. 


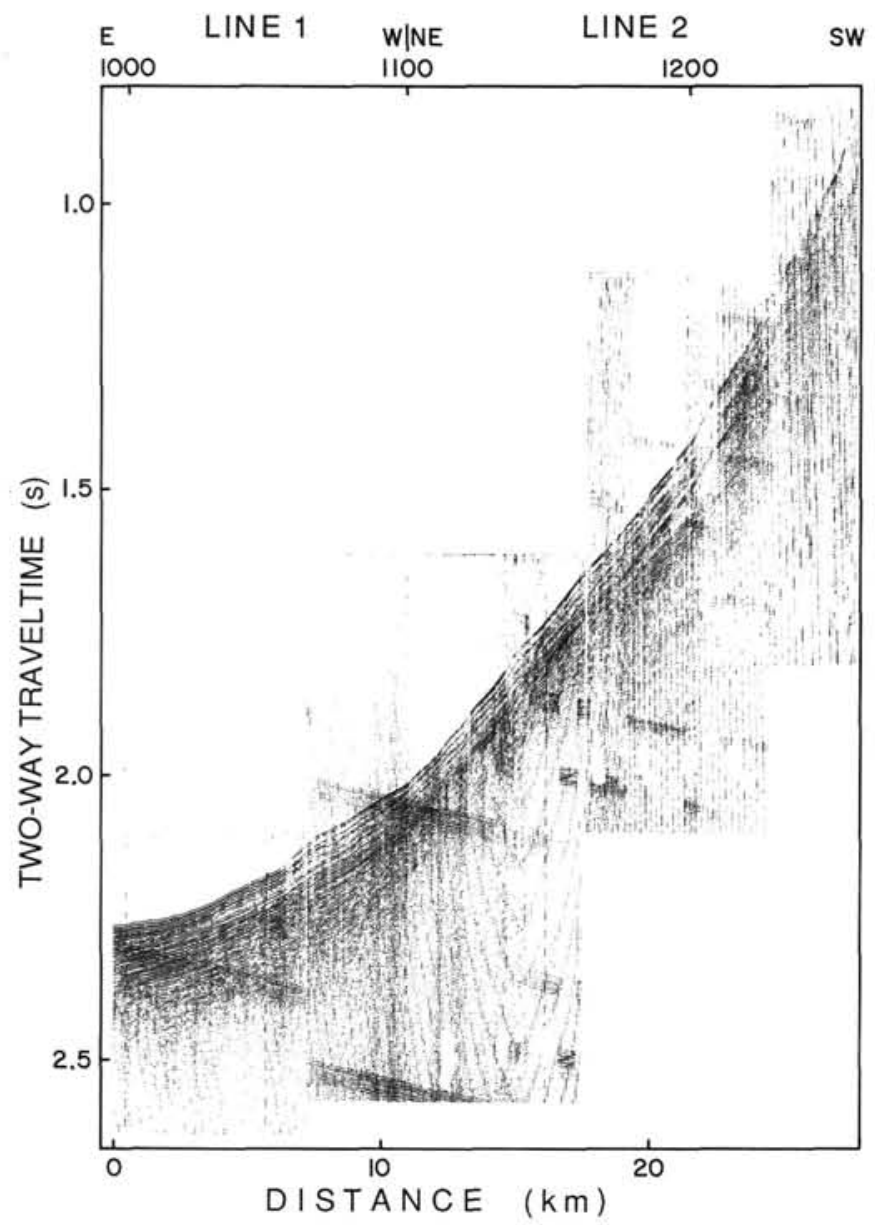

Figure 44. High-resolution seismic profile near Site 645 whose location is shown in Figure 22. 


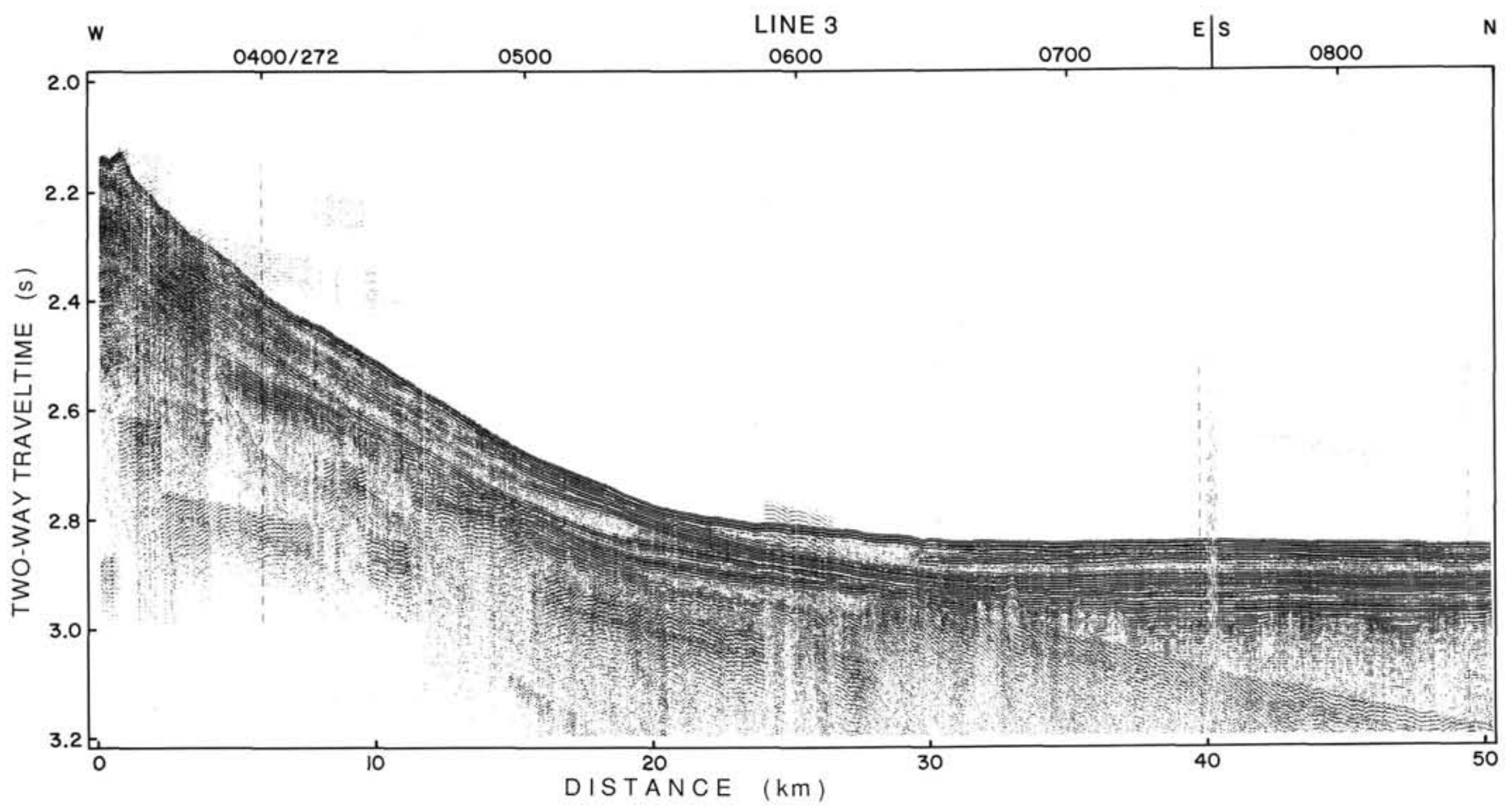

Figure 45. High-resolution seismic profile near Site 645 whose location is shown in Figure 22.

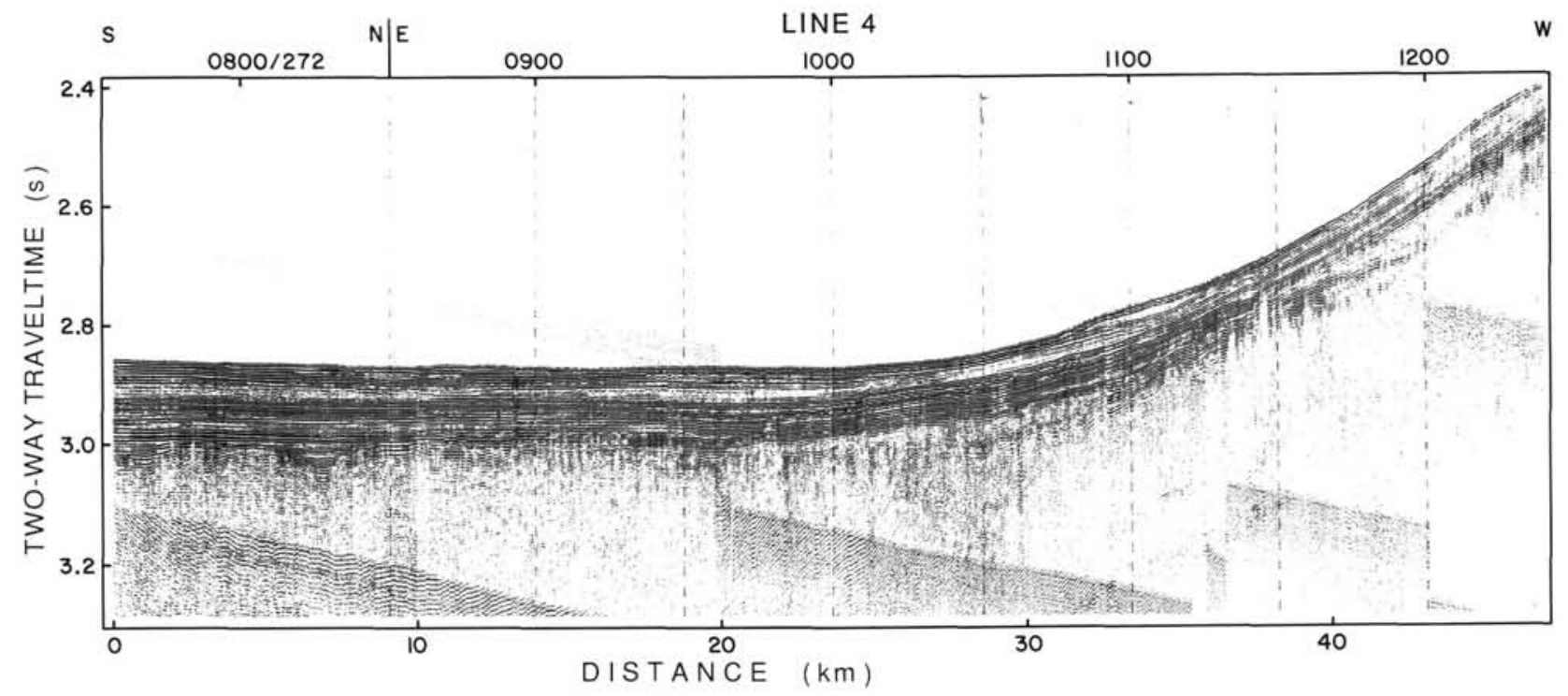

Figure 46. High-resolution seismic profile near Site 645 whose location is shown in Figure 22. 


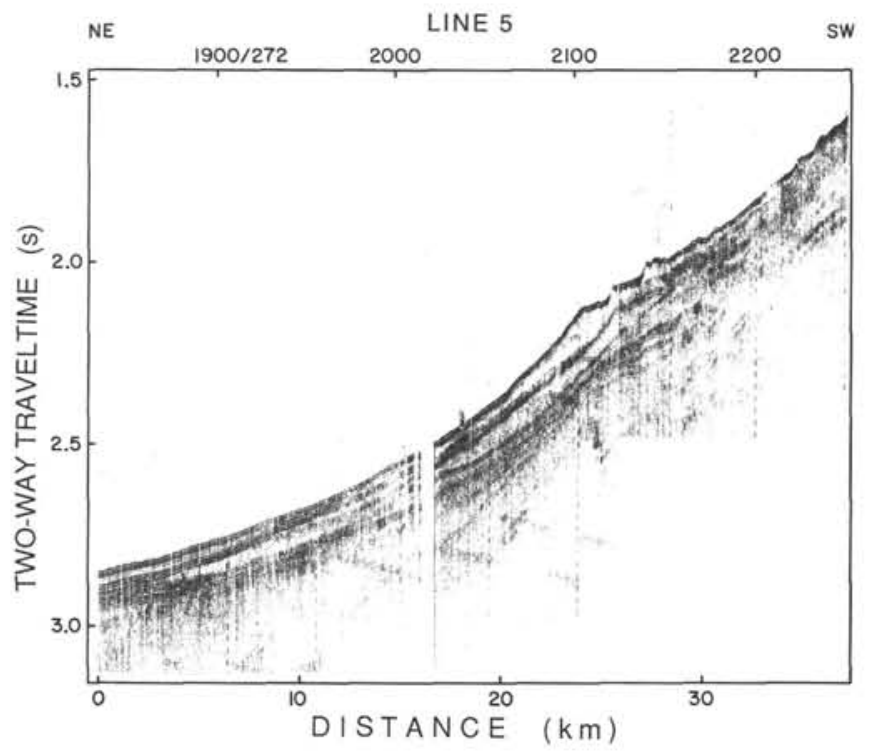

Figure 47. High-resolution seismic profile near Site 645 whose location is shown in Figure 22.

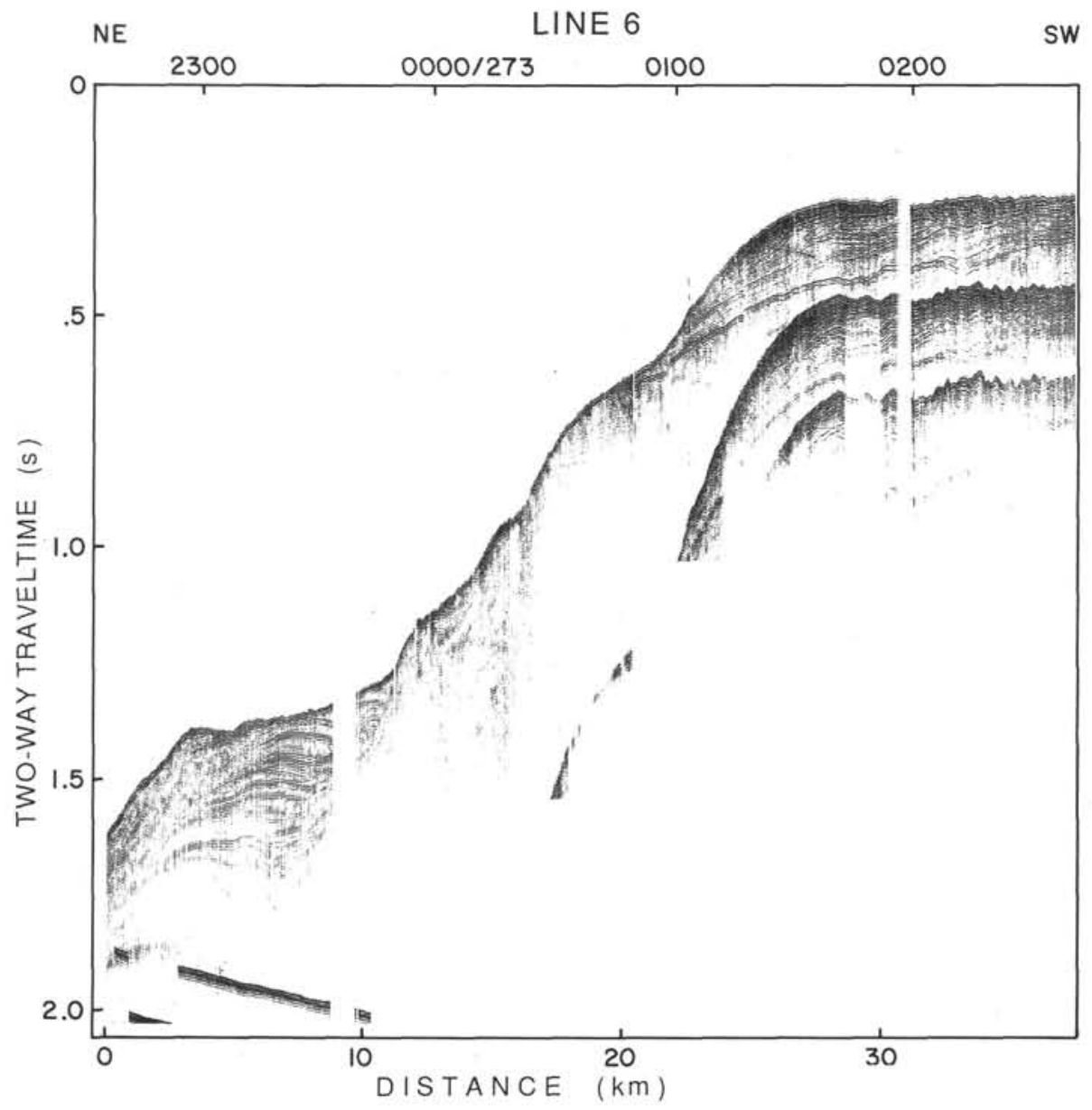

Figure 48. High-resolution seismic profile near Site 645 whose location is shown in Figure 22. 